\title{
ГЕОХИМИЯ И ИЗОТОПНЫЙ СОСТАВ ПАЛЕОПРОТЕРОЗОЙСКИХ КРЕМНЕКИСЛЫХ МАГМАТИТОВ ЕЛАШСКОГО ГРАБЕНА: СВИДЕТЕЛЬСТВА ГЕТЕРОГЕННОСТИ РАННЕДОКЕМБРИЙСКОЙ КОРЫ
}

Ножкин А. Д., Туркина О. М., Савко К. А.

\begin{abstract}
Аннотация
Представлены результаты петрогеохимического и изотопно-геохронологического изучения пород гранит-лейкогранитной ассоциации Павловского массива и кислых вулканитов в Елашского грабена (Бирюсинский блок, юго-запад Сибирского кратона). Характерной чертой гранитлейкогранитной ассоциации является пространственно-временная связь с жильными аплитами и пегматитами Восточно-Саянской редкометальной провинции. U-Pb возраст циркона из гранитов Павловского массива (1852 \pm 5 млн лет) близок к пегматитам Вишняковского редкометального месторождения (1838ロ3 млн лет). Доминирующие в Павловском массиве биотитовые порфировидные граниты и лейкограниты, которые имеют широкие вариации соотношения щелочей $(\mathrm{K} 2 \mathrm{O} / \mathrm{Na} 2 \mathrm{O}=1.1-2.3)$ и железистости и повышенную глиноземистость, сопоставимы с Sгранитами. Изученные риолиты р. Тагул (SiO2 =71-76\%) имеют низкую железистость, повышенное отношение $\mathrm{K} 2 \mathrm{O} / \mathrm{Na} 2 \mathrm{O}(1.6-4.0)$, низкое $(\mathrm{La} / \mathrm{Yb}) \mathrm{n}=4.1-5.6)$, отчетливый Еu минимум $\left(\mathrm{Eu} / \mathrm{Eu}^{*}=0.3-0.4\right)$ и отвечают сильно фракционированным I-гранитам. Вся совокупность близких по возрасту позднепалеопротерозойских (1.88-1.85 млрд лет) гранитов и кислых вулканитов Елашского грабена имеет отчетливые различия в вещественных характеристиках, таких как железистость и содержание тяжелых РЗЭ, связанных вариациями в составе источников и условиях плавления, реализовавшегося в обстановке постколлизионного растяжения. Широкий диапазон изотопных параметров гранитов и кислых вулканитов ( $\varepsilon \mathrm{Nd}$ от +2.0 до -3.7$)$ и цирконов ( $\varepsilon \mathrm{Hf}$ от +3.0 до +0.8 , граниты Топорокского массива) свидетельствует о гетерогенности коры в основании Елашского грабена, формировавшейся как в архее, так и раннем палеопротерозое.
\end{abstract}

\section{Ключевые слова:}

Юго-запад Сибирского кратона, гранитоиды, кислые вулканиты 


\title{
ГЕОХИМИЯ И ИЗОТОПНЫЙ СОСТАВ ПАЛЕОПРОТЕРОЗОЙСКИХ КРЕМНЕКИСЛЫХ МАГМАТИТОВ ЕЛАШСКОГО ГРАБЕНА: СВИДЕТЕЛЬСТВА ГЕТЕРОГЕННОСТИ РАННЕДОКЕМБРИЙСКОЙ КОРЫ
}

\author{
А.Д. Ножкин ${ }^{1}$, О.М. Туркина ${ }^{1.2}$, К.А. Савко ${ }^{3}$ \\ ${ }^{1}$ Институт геологии и минералогии им. В.С. Соболева СО РАН, Новосибирск \\ ${ }^{2}$ Новосибирский государственный университет \\ ${ }^{3}$ Воронежский государственный университет
}

\begin{abstract}
Аннотация
Представлены результаты петрогеохимического и изотопно-геохронологического изучения пород гранит-лейкогранитной ассоциации Павловского массива и кислых вулканитов в Елашского грабена (Бирюсинский блок, юго-запад Сибирского кратона). Характерной чертой гранит-лейкогранитной ассоциации является пространственновременная связь с жильными аплитами и пегматитами Восточно-Саянской редкометальной провинции. U-Pb возраст циркона из гранитов Павловского массива (1852 \pm 5 млн лет) близок к пегматитам Вишняковского редкометального месторождения (1838 3 млн лет). Доминирующие в Павловском массиве биотитовые порфировидные граниты и лейкограниты, которые имеют широкие вариации соотношения щелочей $\left(\mathrm{K}_{2} \mathrm{O} / \mathrm{Na}_{2} \mathrm{O}=1.1-2.3\right)$ и железистости и повышенную глиноземистость, сопоставимы с Sгранитами. Изученные риолиты р. Тагул $\left(\mathrm{SiO}_{2}=71-76 \%\right)$ имеют низкую железистость, повышенное отношение $\mathrm{K}_{2} \mathrm{O} / \mathrm{Na}_{2} \mathrm{O}(1.6-4.0)$, низкое $\left.(\mathrm{La} / \mathrm{Yb})_{\mathrm{n}}=4.1-5.6\right)$, отчетливый $\mathrm{Eu}$ минимум $\left(\mathrm{Eu} / \mathrm{Eu}^{*}=0.3-0.4\right)$ и отвечают сильно фракционированным І-гранитам. Вся совокупность близких по возрасту позднепалеопротерозойских (1.88-1.85 млрд лет) гранитов и кислых вулканитов Елашского грабена имеет отчетливые различия в вещественных характеристиках, таких как железистость и содержание тяжелых РЗЭ, связанных вариациями в составе источников и условиях плавления, реализовавшегося в обстановке постколлизионного растяжения. Широкий диапазон изотопных параметров гранитов и кислых вулканитов $\left(\varepsilon_{\mathrm{Nd}}\right.$ от +2.0 до -3.7$)$ и цирконов $\left(\varepsilon_{\mathrm{Hf}}\right.$ от +3.0 до +0.8, граниты Топорокского массива) свидетельствует о гетерогенности коры в основании Елашского грабена, формировавшейся как в архее, так и раннем палеопротерозое.

Юго-запад Сибирского кратона, гранитоиды, кислые вулканиты, изотопия Nd, палеопротерозойская ювенильная кора
\end{abstract}

\section{Введение}

Раннепротерозойские гранитоиды широко распространены в краевых выступах фундамента (Ангаро-Канский, Бирюсинский, Шарыжалгайский) на юго-западе Сибирской платформы. Гранитоидный магматизм был связан с палеопротерозойской коллизией блоков раннедокембрийской коры и формированием Сибирского кратона. Образование основного объема гранитоидов в этих выступах произошло на постколлизионном этапе в узком временном диапазоне (1.88-1.84 млрд лет). Немногочисленные массивы более поздних (1.75-1.74 млрд лет) внутриплитных гранитов и чарнокитов (кузеевитов) установлены только в Анагаро-Канском и Бирюсинском блоках [Бибикова и др., 2001; Туркина и др., 2006; Ножкин и др., 2009]. Палеопротерозойские гранитоиды характеризуются разнообразием петрохимического состава и редкоэлементных 
характеристик, что определяет их принадлежность к разным петролого-геохимическим типам, включающим I-, А- и S-граниты [Туркина и др., 2006; Донская и др., 2014; Туркина, Капитонов, 2019].

Выходы раннепротерозойских гранитоидов установлены преимущественно среди раннедокембрийских амфиболито-гнейсовых и гранулито-гнейсовых метаморфических комплексов. Особый интерес представляет исследование состава, изотопных характеристик и определение возраста гранитоидов среди нижнепротерозойских метавулканогенно-осадочных отложений в Елашском грабене, перекрывающим гранулитогнейсовое основание на северо-востоке Бирюсинского блока. Это позволяет определить временные и генетические соотношения гранитоидов с вулканическими толщами, развитыми в этой структуре. В настоящей работе рассматриваются геохимическая характеристика пород, данные о U-Pb возрасте циркона и изотопном $\mathrm{Nd}$ составе гранитоидов Павловского массива, размещенного среди нижнепротерозойских метавулканогенно-осадочных толщ Елашского грабена и результаты их сопоставления с данными по кислым вулканитам для оценки характера источников расплавов и обоснования гетерогенности коры фундамента этой структуры.

\section{Геологическое положение и состав гранитоидов Павловского массива}

Бирюсинский блок является частью Присаянского краевого выступа фундамента Сибирской платформы, располагаясь на северо-западном продолжении Шарыжалгайского блока. Эти блоки разделены Урикско-Ийским грабеном, выполненным нижнепротерозойскими метавулканогенно-осадочными толщами. На северо-востоке Бирюсинский блок ограничен Присаянским прогибом, выполненным поздненеопротерозойскими субплатформенными осадочными отложениями, а на югозападе - Главным разломом Восточного Саяна.

Бирюсинский блок образован позднеархейским метаморфическим комплексом, известным как хайламинская серия, который несогласно перекрыт нижнепротерозойскими метаосадочными ассоциациями неройской и метаосадочно-вулканогенными толщами елашской серий (рис. 1) [Эволюция..., 1988; Туркина и др., 2006; Дмитриева, Ножкин, 2012]. Структура раннедокембрийских комплексов определяется сочетанием линейновытянутых поднятий и прогибов, нередко ограниченных разломами северо-западного простирания [Сезько, 1988; Брынцев, 1994]. Поднятия сложены преимущественно мигматизированными гнейсами хайламинского комплекса, гранитогнейсами, мигматитами и чарнокитами, отнесенными к хадаминскому комплексу позднего архея [Легенда ..., 1988; Государственная..., 2000]. В составе хайламинского комплекса преобладают 
биотитовые, гранат-биотитовые, реже амфиболовые и глиноземистые парагнейсы с редкими горизонтами метабазитов. Эти породы метаморфизованы преимущественно в условиях амфиболитовой фации, время метаморфизма оценивается 1.9 млрд лет [Туркина и др., 2006]. Данные о возрасте протолитов метаморфических пород хайламинского комплекса отсутствуют. В пользу их раннедокембрийского (позднеархейского) возраста свидетельствуют значения модельного Nd возраста гнейсов $\mathrm{T}_{\mathrm{Nd}}(\mathrm{DM})=2.6-2.8$ млрд лет [Туркина и др., 2006]. K структурам архейского мигматитгнейсового фундамента приурочены палеопротерозойские (1.88-1.75 млрд лет) коллизионные и внутриплитные гранитоиды [Левицкий и др., 2002; Туркина и др., 2006; Ножкин и др., 2009; Донская и др., 2014]. Протяженный ( 350 км) пояс таких гранитоидов вытянут вдоль Бирюсинского разлома и на значительной площади перекрыт поздненеопротерозойскими осадочными отложениями Присаянского прогиба. Реже гранитоиды развиты среди нижнепротерозойских вулканогенно-осадочных отложений елашской серии в одноименном грабене. Граниты прорывают как мигматит-гнейсовый хайламинский и чарнокит-гнейсовый хадаминский комплексы, так и вулканогенноосадочные образования елашской серии и по тектоническим зонам контактируют с позднепалеопротерозойскими породами неройской серии Туманшетского прогиба [Дмитриева, Ножкин, 2012; Донская и др., 2014; Туркина, Прияткина, 2017].

Палеопротерозойские метаосадочные породы неройской серии распространены к юго-западу от Бирюсинского разлома, где слагают довольно крупный (около 5000 км2) Туманшетский прогиб [Дмитриева, Ножкин, 2012] и ряд более мелких структур среди архейского мигматит-гнейсового основания [Сезько, 1990; Брынцев, 1994; Геря и др., 1997]. Петрогеохимическая характеристика метаосадочных (терригенных) пород неройской серии, результаты реконструкции их протолитов и $\mathrm{Nd}$ изотопные данные $\left(\mathrm{T}_{\mathrm{Nd}}(\mathrm{DM})=1.9-2.7\right.$ млрд лет) свидетельствуют об участии в осадконакоплении пород как архейской, так и палеопротерозойской коры [Дмитриева, Ножкин, 2012].

Метавулканогенно-осадочные толщи елашской серии развиты в одноименном грабене на северо-востоке Бирюсинского блока. Елашский грабен и располагающуюся севернее Большереченскую грабен-синклиналь рассматривают как сохранившиеся фрагменты единого прогиба, именуемого Тагульским [Брынцев, 1994]. Елашский грабен заложен на раннедокембрийском мигматит-гнейсовом основании, реликты которого обнажены среди метавулканогенно-осадочных пород. По тектоническим нарушениям грабен граничит с поздненеопротерозойскими осадочными отложениями (рис. 1). Елашская серия объединяет две толщи: часовенскую и мальцевскую [Галимова и др., 2012]. Нижняя, часовенская толща сложена метапесчаниками, филлитизированными 
сланцами и амфиболитами по базальтоидам [Ножкин, 1999; Галимова и др., 2012; Донская и др., 2019]. Верхняя, мальцевская толща представлена метатерригенными породами, туфами и эффузивами основного, среднего, кислого состава, в том числе субщелочного характера. В палеовулканической структуре зафиксированы породы субвулканической, жерловой и дайковой фаций, представленные метадолеритами, метадиоритами, гранитпорфирами, дацитами и риолитами [Брынцев, 1994; Ножкин, 1999]. Терригенные породы аркозовые и вулканомиктовые песчаники, а также филлитизированные сланцы обогащены радиоактивными элементами (U=3.1-4 г/т, $\mathrm{Th}=13-17$ г/т, $\mathrm{K}=2.4-3.5 \%), \mathrm{Rb}$ и Ва, свидетельствующими о наличии Na-K гранитоидов в близлежащих блоках сиалического основания, подвергавшихся эрозии [Ножкин, 1999]. Среди вулканогенных пород по петрогеохимическим данным выделяются метабазальты, метаандезибазальты и андезиты и метадацит-риолиты [Ножкин, 1999]. На некоторых участках преобладают вулканиты кислого состава. Исследование U-Pb методом циркона из метариолитов мальцевской толщи показало, что они имеют возраст 1872-1874 млн лет [Донская и др., 2019].

В пределах Елашского грабена размещается ряд гранитоидных массивов саянского комплекса (Большереченский, Мироновский, Павловский, Топорокский и др.), сложенных преимущественно биотитовыми и двуслюдяными гранитами и лейкогранитами [Брынцев, 1994; Галимова и др., 2012]. В пространственной связи с ними находится известная Восточно-Саянская провинция редкометальных пегматитов [Загорский и др., 1997; Загорский и др., 2014]. Непосредственно в Елашском грабене расположены Вишняковское и Александровское поля сподумен-петалитовых пегматитов [Загорский и др., 1997].

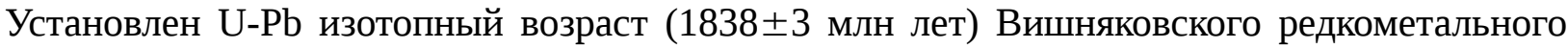
(Ta, Li, Be, Sn, Rb, Cs) месторождения [Сальникова и др., 2011], одного из наиболее крупных объектов этой провинции. Тектоническое положение этого месторождения, также как и гранитов саянского комплекса, определяется принадлежностью к палеопротерозойскому коллизионному магматическому поясу (1.88-1.84 млрд лет).

Изученный Павловский гранитный массив ( 50 км²$\left.^{2}\right)$ расположен в правобережье р. Тагул, в междуречье рч. Яшка и рч. Павловский и к северо-западу от них в бассейне р. Тагул (выше устья рч. Часовенский), где постепенно сменяется лейкогранитами, относящимися к Мироновскому массиву (рис. 2). Павловский массив сложен биотитовыми и двуслюдяными гранитами и лейкогранитами. В подчиненном количестве, обычно в приконтактовых зонах, на границе с амфиболитами и метагабброидами, которые прорываются гранитами, отмечены амфиболовые и биотит-амфиболовые плагиограниты.

Биотитовые граниты это светло-серые и розово-серые равномерно-среднезернистые или слабо порфировидные породы, а двуслюдяные граниты и лейкограниты - розовато- 
серые средне- и мелкозернистые. Биотитовые граниты состоят (\%) из калиевого полевого шпата (30-35), плагиоклаза (27-30), кварца (30-35) и биотита (7-10). Калиевый полевой шпат представлен микроклином со слабо выраженной микроклиновой решеткой или микроклин-пертитом, иногда по нему развивается шахматный альбит. Плагиоклаз олигоклаз-альбит, обычно без видимых полисинтетических двойников, но часто зонален, судя по развитию вторичных минералов в центральной части таблитчатых зерен и «чистого» альбита по их периферии. Биотит, отчетливо плеохроирующий в коричневых тонах, проявляется в виде агрегатов мелких чешуек и отдельных пластинок в межзерновом пространстве кварца и полевых шпатов, он в различной степени замещен хлоритом. Из вторичных минералов присутствуют единичные зерна эпидота, иногда обрастающего ортит. Граниты имеют гипидиоморфнозернистую структуру.

Двуслюдяные граниты отличаются наличием наряду с биотитом равновесного с ним мусковита. В лейкогранитах повышено содержание кварца, иногда калиевого полевого шпата, плагиоклаз представлен альбитом. Преобладающая структура этих пород аллотриоморфная.

В амфиболовых и амфибол-биотитовых плагиогранитах присутствует амфибол зеленая роговая обманка (10-15\%); содержание плагиоклаза (олигоклаз-андезин) увеличивается до 40-45\%, а доля калиевого полевого шпата снижается до 5-10\%. Плагиоклаз представлен идиоморфными полисинтетически сдвойникованными табличками, иногда зонален с внешней альбитовой каймой. Акцессорные минералы включают сфен, апатит, циркон, ильменит, ортит, эпидот.

С гранит-лейкогранитовой ассоциацией Елашского грабена пространственно и генетически связаны пегматитовые жилы, несущие редкометальную минерализацию [Брынцев, 1994]. В пересечении р. Тагул на протяжении 15-17 км нами установлено 5 пегматитовых полей, размещенных среди биотитовых порфировидных гранитов и лейкогранитов и во вмещающих гнейсах и метагабброидах. Видимая мощность жил изменяется от 10-20 см до 5-7 метров. Среди них установлены микроклин-альбитовые пегматиты с акцессорной редкометальной (Ta, Li, Sn и др.) минерализацией, а также шлировые пегматиты, для которых генетическая связь с гранитоидым массивом вполне очевидна.

\section{Методы исследования}

Анализ пород на петрогенные и редкие элементы выполнен в ЦКП Многоэлементных и изотопных исследований СО РАН (г. Новосибирск). Основные породообразующие оксиды $\left(\mathrm{SiO}_{2}, \mathrm{TiO}_{2}, \mathrm{Al}_{2} \mathrm{O}_{3}, \mathrm{Fe}_{2} \mathrm{O}_{3}, \mathrm{CaO}, \mathrm{MgO}\right)$ (табл. 1) определены 
фотометрическим методом, $\mathrm{Na}_{2} \mathrm{O}, \mathrm{K}_{2} \mathrm{O}, \mathrm{MnO}$ - методом атомной абсорбции, $\mathrm{FeO}$ объемным титрованием. Пределы обнаружения этих оксидов 0.3-0.01\%. В отдельных пробах петрогенные элементы определены методом РФА на рентгеновском спектрометре ARL-9900-XP фирмы Thermo Elektron Corporation. Пределы обнаружения петрогенных оксидов от 0.1 до 0.04\%. Концентрации редких элементов в гранитах и кислых метавулканитах определены методом ICP MS на масс-спектрометре высокого разрешения ELEMENT (Finigan Mat) с ультразвуковым распылителем 5000AT+ по методике [Николаева и др., 2008], а в метабазальтах - инструментальным нейтронноактивационным методом. Пределы обнаружения редкоземельных и высокозарядных элементов составляют от 0.005 до 0.1 г/т. Точность анализа составляла в среднем 2-7 отн. $\%$.

$\mathrm{U}-\mathrm{Pb}$ датирование цирконов из гранита выполнено на ионном микрозонде SHRIMP-II в Центре изотопных исследований (ЦИИ) ВСЕГЕИ (г. Санкт-Петербург) (аналитик Ларионов А.Н.) по принятой методике [Williams, 1998]. Для выбора участков (точек) датирования использовались оптические (в проходящем и отраженном свете) и катодолюминисцентные изображения, отражающие внутреннюю структуру и зональность цирконов. Интенсивность первичного пучка молекулярного кислорода составляла 4 нА, диаметр пятна (кратера) составлял 25 мкм при глубине 2 мкм. Обработка полученных данных осуществлялась с использованием программы SQUID [Ludwig, 2000]. U-Pb отношения нормализовались на значение 0.0668, приписанное стандартному циркону TEMORA с возрастом 416.75 млн. лет. Погрешности единичных анализов (отношений и возрастов) приводятся на уровне $1 \sigma$, погрешности вычисленных значений конкордантных возрастов и пересечений с конкордией приводятся на уровне $2 \sigma$. Построение графиков с конкордией проводилось с использованием программы ISOPLOT/EX [Ludwig, 1999].

Определение изотопных составов Sm и Nd выполнены в Геологическом институте Кольского научного центра РАН (г. Апатиты, аналитик П.А. Серов) на семиканальном масс-спектрометре Finnigan MAT-262 (RPQ) в статическом режиме по методике, описанной Т.Б. Баяновой [2004]. Холостое внутрилабораторное загрязнение составило 0.06 нг для Sm и 0.3 нг для $\mathrm{Nd}$. Точность определения концентраций Sm и $\mathrm{Nd} \pm 0.2 \%$ (2б). Изотопные отношения $\quad{ }^{143} \mathrm{Nd} /{ }^{144} \mathrm{Nd} \quad$ нормализованы $\quad$ к $\quad{ }^{148} \mathrm{Nd} /{ }^{144} \mathrm{Nd}=0.251578$, что соответствует отношению ${ }^{146} \mathrm{Nd} /{ }^{144} \mathrm{Nd}=0.7219$ и приведены ${ }^{143} \mathrm{Nd} /{ }^{144} \mathrm{Nd}=0.511860$ в $\mathrm{Nd}$ стандарте La Jolla. Качество измерений контролировалось измерением изотопных стандартов. За период исследования средневзвешенные значения ${ }^{143} \mathrm{Nd} /{ }^{144} \mathrm{Nd}$ отношения для стандарта La Jolla (n=15) составили $0.511833 \pm 15$ (2б). Одностадийный модельный возраст $\quad \mathrm{T}_{\mathrm{Nd}}(\mathrm{DM}) \quad$ рассчитан $\quad$ относительно деплетированной $\quad$ мантии $\quad$ (DM) 
$\left({ }^{147} \mathrm{Sm} /{ }^{144} \mathrm{Nd}=0.2136\right.$ и $\left.{ }^{143} \mathrm{Nd} /{ }^{144} \mathrm{Nd}=0.51315\right)$, величины $\varepsilon_{\mathrm{Nd}}(\mathrm{t})$ определены относительно CHUR $\left({ }^{147} \mathrm{Sm} /{ }^{144} \mathrm{Nd}=0.1967\right.$ и $\left.{ }^{143} \mathrm{Nd} /{ }^{144} \mathrm{Nd}=0.512638\right)$.

\section{U-Pb возраст циркона из гранитоидов Павловского массива}

Для изотопно-геохронологического исследования отобрана проба (А-257-81) биотитового порфировидного гранита в правом борту р. Тагул, в 2.5 км ниже руч. Павловский (рис.2). Выделенные цирконы представлены призматическими и призматически-дипирамидальными коричневыми непрозрачными и полупрозрачными кристаллами хорошо ограненными, размером от 200 до 700 мкм и $\mathrm{K}_{\mathrm{yд}}=2-3$, реже до 5. В катодолюминисцентном изображении (КЛ) большинство кристаллов характеризуется отчетливой осцилляторной зональностью. Реже встречаются цирконы со слабо проявленной или нарушенной ростовой зональностью (темные в КЛ), что обусловлено их метамиктностью и процессами перекристаллизации. В отличие от зональных кристаллов (U=105-455г/т; Th=30-284 г/т; Th/U=0.5-0.7) темные и незональные в КЛ зерна обогащены $\mathrm{U}(1129-2975$ г/т) и в меньшей мере Th (104-325 г/т) и характеризуются пониженным Th/U (0.02-0.27). Проанализировано 11 зерен циркона (табл. 1). Конкордантный возраст семи зерен составляет $1847 \pm 7$ млн лет $(\mathrm{CKBO}=3.3)(2 \sigma)$ (рис. 3). На диаграмме с конкордией точки изотопного состава всех зерен образуют дискордию с верхним пересечением с конкордией, отвечающим возрасту $1859 \pm 8$ млн лет(СКВО=0.87), что в пределах ошибки соответствует конкордантному возрасту. Средневзвешенный возраст по 13 точкам составляет $1852 \pm 5$ млн лет $(\mathrm{CKBO}=1.2)$. Учитывая морфологию циркона, наличие в большинстве зерен отчетливой осцилляторной зональности, указывающей наряду с величиной $\mathrm{Th} / \mathrm{U}(0.5-0.7)$ на его магматическое происхождение, возраст $1852 \pm 5$ млн лет можно принять как время образования гранитов Павловского массива.

\section{Геохимия и изотопный Nd состав гранитоидов Павловского массива}

В биотитовых порфировидных гранитах содержание $\mathrm{SiO}_{2}$ варьирует от 70 до 76.8\%; $\mathrm{K} 2 \mathrm{O}$ от 3.0 до 5.6\%, отношение $\mathrm{K}_{2} \mathrm{O} / \mathrm{Na}_{2} \mathrm{O}$ изменяется в интервале 1.1-2.3 (табл. 2). Согласно классификации [Frost et al., 2001] состав этих гранитоидов изменяется от магнезиального до железистого $\left(\mathrm{FeO}^{*} /(\mathrm{FeO} *+\mathrm{MgO})=0.68-0.9\right)$ типов с ростом железистости при увеличении $\mathrm{SiO}_{2}$, по индексу $\left(\mathrm{Na}_{2} \mathrm{O}+\mathrm{K}_{2} \mathrm{O}-\mathrm{CaO}\right)$ они варьируют от щелочно-известковистых до известково-щелочных (MALI=4.2-8.7) и являются слабо пералюминиевыми (ASI=1.04-1.3) (рис. 4). В биотитовых гранитах в сравнении с лейкогранитами повышено содержание Th (23-40 г/т), Zr, Hf, Та и легких редкоземельных элементов (табл. 2). Спектры Р3Э биотитовых гранитов более дифференцированные 
$\left.(\mathrm{La} / \mathrm{Yb})_{\mathrm{n}}=14-18\right)$ в сравнении с лейкогранитами $\left.(\mathrm{La} / \mathrm{Yb})_{\mathrm{n}}=3.5-4.5\right)$. Те и другие характеризуются отчетливым $\mathrm{Eu}$ минимумом $\quad\left(\mathrm{Eu} / \mathrm{Eu}^{*}=0.3-0.7\right) \quad$ (рис. 5a, в) На мультиэлементных спектрах биотитовых гранитов и лейкогранитов проявлены максимумы по $\mathrm{Rb}$, Th и минимумы по $\mathrm{Ba}$, $\mathrm{Nb}(\mathrm{Ta}), \mathrm{Sr}, \mathrm{P}$ и $\mathrm{Ti}$, что обусловлено дифференциацией исходного расплава с фракционированием плагиоклаза, апатита и ильменита (рис. 5б, г). В целом содержание высокозарядных элементов ( $\mathrm{Zr}, \mathrm{Hf}, \mathrm{Nb}, \mathrm{Ta})$ и Р3Э в биотитовых гранитах и особенно лейкогранитах понижено в сравнении со средними их концентрациями в Na-K гранитах [Интерпретация..., 2001]. Сочетание повышенной глиноземистости с широкими вариациями $\left(\mathrm{FeO}^{*} /\left(\mathrm{FeO}^{*+\mathrm{MgO})}\right.\right.$ позволяет отнести эти гранитоиды к S-гранитам или дифференцированным I-гранитам.

Представительная характеристика гранитоидов Павловского массива получена по распределению радиоактивных элементов (РАЭ) (табл. 3). Повышенные концентрации РАЭ и особенно Тh присущи биотитовым порфировидным гранитам, состав которых вероятно наиболее близок к составу исходной гранитоидной магмы. Лейкограниты, как дифференциаты этой магмы, обогащены $\mathrm{SiO}_{2}$ и $\mathrm{K}_{2} \mathrm{O}$, обеднены $\mathrm{Th}$ и другими высокозарядными элементами. Все разновидности гранитов характеризуются нормальным (4-6) Th/U отношением. В отличие от гранитоидов в ассоциирующих пегматитах Th/U значительно ниже ( 1.5), кроме того, альбитизированные редкометальные пегматиты отличаются низким содержанием калия. Кислые вулканиты по содержанию Th и U сопоставимы с лейкогранитами, но отличаются пониженным содержанием калия.

Согласно Sm-Nd изотопным данным порфировидный гранит (обр. 258-81) имеет $\varepsilon_{\mathrm{Nd}}(\mathrm{t})=-3.3$ и модельный возраст $\mathrm{T}_{\mathrm{Nd}}(\mathrm{DM})=2672$ млн лет, по величине модельного возраста он отвечает диапазону для пара- и ортогнейсов хайламинского комплекса $\left(\mathrm{T}_{\mathrm{Nd}}(\mathrm{DM})=2.6-2.8\right.$ млрд лет)(табл. 4). Плагиогранит (обр. 253-81) характеризуется более высоким $\varepsilon_{\mathrm{Nd}}(\mathrm{t})=-2.0$ и раннепротерозойским модельным возрастом $-\mathrm{T}_{\mathrm{Nd}}(\mathrm{DM})=2347$ млн лет.

\section{Состав вулканитов елашской серии}

В изученном авторами разрезе по р. Тагул среди вулканогенных пород выделяется три ассоциации: метабазальтовая, метадацит-риолитовая, метабазальт-андезибазальтандезитовая. Породы метабазальтовой ассоциации развиты среди терригенных отложений часовенской толщи. Эти породы отвечают толетовой серии и слабо дифференцированы от мелано- до лейкобазальтов. Породы характеризуются пониженной магнезиальностью (Mg\# =55-42), умеренным содержанием $\mathrm{TiO}_{2}$ (1.94-1.0 \%) и $\mathrm{P}_{2} \mathrm{O}_{5}$ (0.15-0.24\%). Для них типичны субгоризонтальные спектры Р3Э $\left.(\mathrm{La} / \mathrm{Yb})_{\mathrm{n}}=1.0-1.2\right)$ и рост концентраций лантаноидов с уменьшением Mg\# (рис. 6а),. На мультиэлементных спектрах слабо 
проявлено обогащение LIL элементами и Sr и отрицательные до положительных аномалии по Та (рис. 6б). Породы андезибазальт-андезитовой ассоциации отличаются пониженным $\mathrm{Mg \#} \mathrm{(56-44)} \mathrm{и} \mathrm{низким} \mathrm{содержанием} \mathrm{TiO}_{2}$ (1.14-0.87\%). В сравнении с породами метабазальтовой ассоциации они обогащены Th (4.6-7.2 г/т) и легкими лантаноидам, что приводит к слабо фракционированному спектру Р3Э $\left.(\mathrm{La} / \mathrm{Yb})_{n}=4.9\right)$ со слабой аномалией по

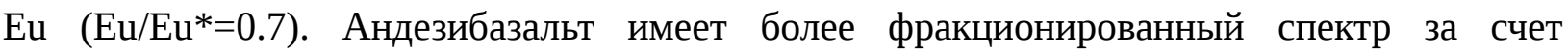
обогащения легкими РЗЭ и крупноионными литофильными элементами и более выраженный минимум по Та (рис. 6а).

Кислые метавулканиты имеют преимущественно риолитовый состав $\left(\mathrm{SiO}_{2}=71\right.$ 76\%), низкую железистость $\left(\mathrm{FeO} /\left(\mathrm{FeO}^{*}+\mathrm{MgO}\right)=0.73-0.87\right)$ (рис. 4) и повышенное отношение $\mathrm{K}_{2} \mathrm{O} / \mathrm{Na}_{2} \mathrm{O}$ (1.6-4.0). Породы умеренно обогащены Th (10.3-16 г/т) и Ва (370-909 г/т) при пониженном содержании Rb (72-152 г/т). Спектры Р3Э риолитов слабо фракционированные $\left.(\mathrm{La} / \mathrm{Yb})_{\mathrm{n}}=4.1-5.6\right)$ вследствие обогащения тяжелыми лантаноидами с отчетливым Eu минимумом (Eu/Eu*=0.3-0.4) (рис. 6в). На мультиэлементных спектрах резко проявлены минимумы по Sr и Ti и более слабое обеднение Nb (рис. 6г).

Метабазальт часовенской толщи елашской серии характеризуется высоким положительным значением $\varepsilon_{\mathrm{Nd}}(\mathrm{t})(+3.5)$, тогда как риодацит - слабым отрицательным $\varepsilon_{\mathrm{Nd}}(\mathrm{t})=-1.4$ и модельным Nd возрастом 2.5 млрд лет (табл. 4).

\section{Обсуждение результатов}

Ассоциация лейкогранитов, пегматитов и кислых вулканитов Елашского прогиба

Павловский массив - один из наиболее крупных массивов гранит-лейкогранитной ассоциации, характеризующийся развитием порфировидных биотитовых гранитов и лейкогранитов, как вероятных продуктов фракционирования одного исходного расплава. Обеднение лейкогранитов Th, легкими Р3Э, Zr, Nb обусловлено отделением остаточного расплава после кристаллизации основной массы акцессорных элементов, что является характерным для высококремнистых магм [Miller, Mittlefehldt, 1982]. Породами гранитлейкогранитной ассоциации сложено большинство массивов саянского комплекса, расположенных в пределах Тагульского прогиба, включающего структуру Елашского грабена [Брынцев, 1994; Галимова и др., 2012, Туркина, Прияткина, 2017]. Павловский массив и другие гранитоидные интрузии этой ассоциации сопровождаются многочисленными жильными телами аплитов, пегматоидных гранитов и пегматитов. Характерной чертой гранит-лейкогранитовой ассоциации является ее пространственновременная связь с литиеносными пегматитами, известными в качестве Восточно-Саянской 
редкометальной провинции [Брынцев, 1994; Загорский и др., 1997; Загорский и др., 2014]. Формирование массивов гранит-лейкогранитной ассоциации и пегматитовых жил происходило синхронно или близко по времени. Так U-Pb изотопный возраст манганотанталита Вишняковского редкометального месторождения в пегматитах

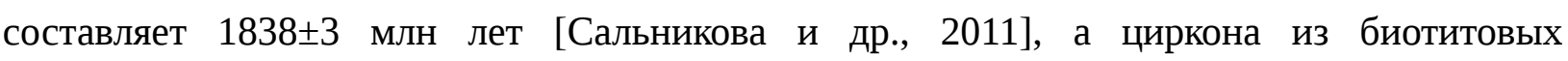

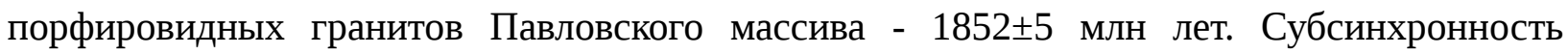
формирования гранитов и пегматитов в одной и той же структуре предполагает их парагенетическую связь.

Палеопротерозойские гранитоиды саянского комплекса в Бирюсинском блоке образуют единый протяженный ( 350 км) магматический пояс [Туркина и др., 2006; Галимова и др., 2012; Донская и др., 2014], приуроченный к линейно-вытянутому поднятию вдоль зоны сочленения Бирюсинского блока Ангарского складчатого пояса и архейского Тунгусского супертеррейна Сибирского кратона. Это поднятие образовано гнейсами хайламинского комплекса, гранитогнейсами, мигматитами и чарнокитами хадаминского комплекса. Состав гранитоидов саянского комплекса в этом поясе весьма разнообразен. На основании результатов петрохимического, геохронологического и изотопно-геохимического исследования кислых вулканических пород мальцевской толщи елашской серии предложено объединить палеопротерозойские гранитоиды и вулканиты в вулкано-плутоническую ассоциацию [Донская и др., 2019] и выделить в качестве СаяноБирюсинского вулкано-плутонического пояса. Следовательно, в структуре ЮжноСибирского постколлизионного магматического пояса [Ларин и др., 2003] предполагается наличие третьего вулкано-плутонического пояса наряду с Северо-Байкальским и УлканДжугджурским. Вместе с тем, вопрос о включении гранитоидов и вулканитов в одну вулкано-плутоническую ассоциацию остается дискуссионным, поскольку, как показано ниже, эти породы, сформированные в течение одного тектоно-магматического этапа, обнаруживают существенные различия по характеру источников и условиям генерации расплавов.

Анализ состава источников и условий образования гранитоидов и кислых вулканитов Елашского прогиба

Близкие по возрасту позднепалеопротерозойские гранитоиды и кислые вулканиты, развитые на сравнительно небольшой территории Елашского прогиба, отличаются удивительным разнообразием вещественных и изотопных параметров, предполагающих различие в характере источников и условиях формирования. Единственной общей их чертой является высокая кремнекислотность $\left(\mathrm{SiO}_{2}=70-77 \%\right)$, свидетельствующая о высокой дифференцированности первичных расплавов, что затрудняет анализ вероятных 
источников магм. Большинство этих кислых магматических пород характеризуется повышенной глиноземистостью (ASI=1.0-1.3), вместе с тем аномально высокие значения ASI (до 3.1) прежде всего кислых вулканитов участка Топорок [Донская и др., 2019] по видимому не являются их первичной чертой, а обусловлены постмагматическими изменениями, результатом которых было резкое обеднение $\mathrm{CaO}(\leq 0.3 \%)$ (рис. 4б). По величине железистости среди гранитоидов и кислых вулканитов обособляется три группы (рис. 4a). Высоко железистая группа включает лейкограниты $(\mathrm{f}=\mathrm{FeO} * /(\mathrm{FeO} *+\mathrm{MgO})=0.94-$ 0.96) Топорокского массива и риолиты $(\mathrm{f}=0.83-0.92)$ Топорокского участка. $\mathrm{K}$ магнезиальным (f=0.72-0.81) разностям относятся кислые вулканиты участка Тагул по данным авторов и [Донская и др., 2019]. Наконец, граниты Павловского массива имеют широкие диапазон железистости $(\mathrm{f}=0.68-0.9)$. Вариации этого параметра отражают различия в условиях генерации исходных расплавов от «сухих» восстановительных для пород участка Топорок до окислительных для риолитов участка Тагул. Промежуточные значения $\mathrm{f}$ установленные для гранитоидов Павловского обуславливают их сходство с гранитоидами S-типа, для которых характерен широкий диапазон этого параметра [Frost et al., 2001]. Контрастные значения рассматриваемого параметра, а также суммарное содержание типоморфных элементов $(\mathrm{Zr}+\mathrm{Nb}+\mathrm{Ce}+\mathrm{Y})$ позволяют сопоставлять высокожелезистые лейкограниты Топорокского массива с гранитоидами А-типа, а магнезиальные и железистые вулканиты с высокодифференцированными I- и Агранитами, соответственно (рис. 4в).

В рассматриваемой совокупности пород резкие различия установлены также по характеру распределения РЗЭ, прежде всего уровню концентраций тяжелых лантаноидов. Сильное обеднение тяжелыми Р3Э $\left(\mathrm{Yb}_{\mathrm{n}} \leq 3.3\right)$ и высокое и сильно варьирующее $(\mathrm{La} / \mathrm{Yb})_{\mathrm{n}}(7-$ 31) имеют кислые вулканиты участка Топорок [Донская и др., 2019], к которым приближаются граниты Павловского массива ( $\left.\mathrm{Yb}_{\mathrm{n}}=5-12, \quad(\mathrm{La} / \mathrm{Yb})_{\mathrm{n}}=3-18\right)$ (рис. 4г). Напротив, риолиты р. Тагул обогащены тяжелыми лантаноидами ( $\left.\mathrm{Yb}_{\mathrm{n}}=11-45\right)$ и обладают низким $(\mathrm{La} / \mathrm{Yb})_{\mathrm{n}} \quad(3.5-10.5)$, близкую степень накопления тяжелых Р3Э имеют лейкограниты Топорокского массива $\left(\mathrm{Yb}_{\mathrm{n}}=15-22\right.$, $\left.(\mathrm{La} / \mathrm{Yb})_{\mathrm{n}}=3-11\right)$. Концентрации тяжелых Р3Э и величина $(\mathrm{La} / \mathrm{Yb})_{n}$ зависят от двух параметров: состава источника и наличия/отсутствия граната среди реститовых фаз, что определяется глубиной генерации расплава. Исходя из немногочисленной информации гнейсы хайламинского комплекса Бирюсинского блока имеют умеренно фракционированное распределение РЗЭ $(\mathrm{La} / \mathrm{Yb})_{\mathrm{n}}=6-18$ с повышенным содержание тяжелых лантаноидов $\left(\mathrm{Yb}_{\mathrm{n}}=10-23\right)$ и отчетливой отрицательной $\mathrm{Eu}$ аномалией $\left(\mathrm{Eu} / \mathrm{Eu}^{*}=0.5-0.8\right)$. Рассматривая эти породы в качестве потенциального источника кислых магм можно полагать, что при образовании 
палеопротерозойских гранитов и кислых вулканитов плавление происходило как в области устойчивости реститового граната, так и без него. Исходя из экспериментальных данных по плавлению, гранат в качестве перитектической фазы появляется для граувакковых субстратов при P $\geq 5$ кбар (Vielzeus, Montel., 1994) и для тоналитовых $\geq 8$ кбар (Watkins et al., 2007). Следовательно, генерация кислых вулканитов участка Топорок и вероятно гранитов Павловского массива происходила при $\mathrm{P} \geq 5$ кбар, тогда как риолитов р. Тагул и лейкогранитов Топорокского массива на меньших глубинах.

Оценка температур генерации кислых расплавов сделана на основании температур насыщения цирконием для гранитоидов и кислых вулканитов, рассчитанных по [Watson, Harrison, 1983]. Согласно [Miller et al., 2003], полученные значения представляют минимальные температуры формирования расплава, поскольку цирконы из этих пород не содержат унаследованных ядер. Максимальными температурами характеризуются лейкограниты Топорокского массива $\left(\mathrm{T}_{\mathrm{zr}}=795-822^{\circ} \mathrm{C}\right)$ и вулканиты р. Тагул $\left(\mathrm{T}_{\mathrm{zr}}=796-818^{\circ} \mathrm{C}\right.$ и 814-816 ${ }^{\circ}$ С, по данным авторов и [Донская и др., 2019], соответственно). Более низкие температуры имеют риолиты участка Топорок $\left(\mathrm{T}_{\mathrm{zr}}=738-766^{\circ} \mathrm{C}\right)$ [Донская и др., 2019] и граниты Павловского массива $\left(\mathrm{T}_{\mathrm{zr}}=687-785^{\circ} \mathrm{C}\right)$. Для первых это вероятно обусловлено высокой степенью фракционирования расплава, что привело к обеднению Zr, а для вторых низкие температуры коррелируют с их принадлежностью к S-типу гранитов, образующихся при плавлении метаосадочных субстратов.

Проведенный анализ свидетельствует о том, что в позднем палеопротерозое кислые расплавы формировались преимущественно за счет магматических и реже осадочных источников (граниты Павловского массива). Плавление происходило в преимущественно в малоглубинных условиях (P $\leq 5$ кбар) за исключением образования риолитов Топорокского участка, резко деплетированных тяжелыми РЗЭ вследствие наличия реститового граната. Температуры генерации исходных расплавов в целом не коррелируют с железистостью пород: близкими значениями характеризуются граниты Топорокского массива и кислые вулканиты р. Тагул, формировавшихся в условиях как низкой, так и высокой активности $\mathrm{H}_{2} \mathrm{O}$. Таким образом, отчетливые различия в геохимических характеристиках одновозрастных гранитоидов и кислых вулканитов Елашского прогиба отражает вещественную неоднородность коры в основании этой структуры и варьирующие РТпараметры плавления в условиях общего постколлизионного растяжения.

Изотопная гетерогенность коры в основании Елашского прогиба

Об изотопных параметрах архейских пород фундамента Елашского прогиба позволяют судить гнейсы хайламинского комплекса, имеющие модельный Nd возраст 2.62.8 млрд лет и на время проявления палеопротерозойского магматизма ( 1.86 млрд лет) 
характеризующиеся $\varepsilon_{\mathrm{Nd}}$ от -4.1 до -6.9. Амфиболиты (метабазальты) и метадолериты, развитые в вулканическом разрезе елашской серии имеют положительные $\varepsilon_{\mathrm{Nd}}(\mathrm{t})+3.5$ и +4.1 до +3.7 , соответственно по данным авторов и [Донская и др., 2019], что указывает на их деплетированный мантийный источник. Синтез данных авторов и из работы [Донская и др., 2019] показывает, что граниты и средне-кислые вулканиты по изотопным параметрам распадаются на две группы. Большинство этих пород характеризуются отрицательными величинами $\varepsilon_{\mathrm{Nd}}(\mathrm{t}):$ от $-3.7 \ldots-4.6$ для андезитов и риолитов мальцевской толщи на участке Топорок [Донская и др., 2019] до -3.3...-2.0 для гранитов Павловского массива Модельный возраст этой группы пород составляет 2.7-2.3 млрд лет, что наряду с величинами $\varepsilon_{\mathrm{Nd}}(\mathrm{t})$ предполагает доминирующий вклад неоархейской коры подобной гнейсам хайламинского комплекса. Вторая группа включает риолит мальцевской толщи, опробованный авторами по р. Тагул $\left(\varepsilon_{\mathrm{Nd}}(\mathrm{t})=-1.4\right)$ и риолит этой же толщи участка Тагул $\left(\varepsilon_{\mathrm{Nd}}(\mathrm{t})=+2.0\right)$ [Донская и др., 2019], эти кислые вулканиты образованы при плавлении ювенильного палеопротерозойского источника или при его доминирующем участии. К этой группе принадлежат и лейкограниты Топорокского массива, магматические цирконы которых с возрастом $\sim 1884$ млн лет характеризуются положительными $\varepsilon_{\mathrm{Hf}}(\mathrm{t})($ от +3.0 до +0.8$)$ и палеопротерозойским двухстадийным модельным возрастом $\mathrm{T}_{\mathrm{Hf}}^{\mathrm{C}}(\mathrm{DM})$ - 2.3-2.5 млрд лет [Туркина, Прияткина, 2017]. Таким образом, исходя из параметров источников кислых расплавов очевидна изотопная гетерогенность и различный возраст коры в фундаменте Елашского прогиба, формировавшейся в течение как архея, так и раннего палеопротерозоя.

Распространение ювенильной палеопротерозойской коры на юго-западе

\section{Сибирского кратона}

Изотопные характеристики гранитоидов и кислых вулканитов Елашского грабена свидетельствуют о наличии в основании этой структуры пород ювенильной палеопротерозойской коры. Время образования такой коры отражают минимальные модельные возрасты пород - $\mathrm{T}_{\mathrm{Nd}}(\mathrm{DM})=2.2$ млрд лет [Донская и др., 2019] и циркона $\mathrm{T}_{\text {Hf }}^{\mathrm{C}}(\mathrm{DM})=2.3$ млрд лет [Туркина, Прияткина, 2017]. Палеопротерозойский коровый источник фиксируют также изотопные параметры лейкогранитов Малобельского массива (Онотский блок Шарыжалгайского выступа) $\left(\mathrm{T}_{\mathrm{Nd}}(\mathrm{DM})=2.3-2.5\right.$ млрд лет и циркона из этих пород $\left(\mathrm{T}_{\text {Hf }}^{\mathrm{C}}(\mathrm{DM})=2.1-2.3\right.$ млрд лет) [Туркина, Капитонов, 2019], расположенного примерно в 400 км к юго-востоку от Елашской структуры. В том и другом случае кислые магматические породы с ювенильными палеопротерозойскими изотопными характеристиками локализованы вблизи северо-восточного ограничения Бирюсинского и Шарыжалгайского блоков, обращенных к внутренней части Сибирского кратона на 
границе с отложениями чехла. Это позволяет предполагать наличие здесь шовной зоны северо-западного простирания, сложенной породными комплексами палеопротерозойской коры с минимальным возрастом отделения от деплетированной мантии 2.1-2.3 млрд лет. Важным индикатором ювенильной палеопротерозойской коры служат детритовые цирконы ( 1.95 и 2.35 млрд лет) из парагнейсов на юго-востоке Иркутного блока (Шарыжалгайский выступ) с минимальным модельным возрастом - $\mathrm{T}_{\text {Hf }}^{\mathrm{C}}(\mathrm{DM}) 2.0$ и 2.3 млрд лет [Туркина и др., 2016]. Находки таких цирконов предполагают развитие ювенильных породных ассоциаций и на уровне верхней коры, подвергавшейся эрозии. При участии палеопротерозойских источников сноса были сформированы и метатерригенные породы неройской серии Туманшетского прогиба, которые характеризуются минимальным значением $\mathrm{T}_{\mathrm{Nd}}(\mathrm{DM})=1.9$ млрд лет [Дмитриева, Ножкин, 2012].

Формирование палеопротерозойской ювенильной коры могло быть связано либо с рифтогенными, либо с субдукционными процессами, но любой сценарий предполагает, что аккреция Бирюсинского и Шарыжалгайского блоков к западному (в современных координатах) краю Тунгусского супертеррейна завершилась только в ходе позднепалеопротерозойских коллизионных процессов.

\section{Выводы}

Проведено петрогеохимическое и изотопно-геохронологическое изучение пород гранит-лейкогранитной ассоциации Павловского массива - одного из наиболее крупных плутонов Елашского грабена в Бирюсинском блоке на юго-западе Сибирского кратона. Характерной чертой гранит-лейкогранитной ассоциации является пространственновременная связь с ней жильных аплитов и литиеносных пегматитов, относящихся к Восточно-Саянской редкометальной провинции. U-Pb возраст циркона из гранитов Павловского массива ( 1.85 млрд лет) близок к пегматитам Вишняковского редкометального месторождения.

Доминирующими в ассоциации являются биотитовые порфировидные граниты, характеризующиеся широкими вариациями соотношения щелочей $\left(\mathrm{K}_{2} \mathrm{O} / \mathrm{Na}_{2} \mathrm{O}=1.1-2.3\right)$ и железистости, и повышенной глиноземистостью. Фракционирование от гранитов к лейкогранитам проявлено в снижении концентраций Тh, высокозарядных элементов, легких Р3Э и увеличении отрицательной $\mathrm{Eu}$ аномалии. Петрогеохимические характеристики позволяют сопоставлять гранитоиды Паловского массива с S-гранитами или высокодифференцированными І-гранитами. 
Близкие по возрасту позднепалеопротерозойские граниты и кислые вулканиты Елашского грабена имеют отчетливые различия в вещественных характеристиках, связанные с вариации в составе источников и условиях генерации расплавов. Широкий диапазон изотопных параметров гранитов и кислых вулканитов $\left(\varepsilon_{\mathrm{Nd}}\right.$ от +2.0 до -3.7$)$ и цирконов $\left(\varepsilon_{\mathrm{Hf}}\right.$ от +3.0 до +0.8 , граниты Топорокского массива) отражает гетерогенность коры в фундаменте Елашского грабена, формировавшейся как в архее, так и раннем палеопротерозое. Граниты и кислые вулканиты Присаянского поднятия трассируют распространение ювенильной палеопротерозойской коры в зоне северо-западного простирания по краю Тунгусского супертеррейна.

Работа выполнена в рамках базового проекта фундаментальных исследований ИГМ СО PAH (№ 0330-2016-0014 и 0330-2016-0003). 


\section{Список литературы}

Баянова Т.Б. Возраст реперных геологических комплексов Кольского региона и длительность процессов магматизма. Санкт-Петербург., Наука, 2004, 174 с.

Бибикова Е.В., Грачева Т.В., Козаков И.К., Плоткина Ю.В. U-Pb возраст гиперстеновых гранитов (кузеевитов) Ангаро-Канского выступа (Енисейский кряж) // Геология и геофизика, 2001, т. 42 (5), с. 864-867.

Брынцев В.В. Докембрийские гранитоиды Северо-Западного Присаянья. Новосибирск, Наука, 1994, 184 с.

Галимова Т.Ф., Пашкова А.Г., Поваринцева С.А., Перфильев В.В., Намолова М.М., Андрющенко С.В., Денисенко Е.П., Пермяков С.А., Миронюк Е.П., Тимашков А.Н., Плеханов А.О. Государственная геологическая карта Российской Федерации. М-б 1 : 1000 000 (третье поколение). Серия Ангаро-Енисейская. Лист N-47 - Нижнеудинск. Объяснительная записка. СПб., Картографическая фабрика ВСЕГЕИ, 2012, 652 с. + 14 вкл.

Геря Т.В., Перчук Л.Л., Трибуле К., Одрен К., Сезько А.И. Петрология туманшетского зонального метаморфического комплекса, Восточный Саян // Петрология, 1997, т. 5 (6), с. 563-595.

Геологическая карта Иркутской области и сопредельных территорий масштаба 1:500000 / Под ред. В.Г. Кузнецова, П.М. Хренова. Министерство геологии СССР. Ленинград, ВСЕГЕИ, 1982. 16 л.

Государственная геологическая карта Российской Федерации масштаба 1:200000. Листы N-47-II и N-47-VIII. Иркутск: ГФУГП, 2000. Авторы Т.Ф. Галимова, С.В. Андрющенко, Л.А. Бормоткина.

Дмитриева Н.В., Ножкин А.Д. Геохимия палеопротерозойских метатерригенных пород Бирюсинского блока юго-западной части Сибирского кратона // Литология и полезные ископаемые, 2012, № 2, с. 156-179.

Донская Т.В., Гладкочуб Д.П., Ковач В.П., Мазукабзов А.М. Петрогенезис раннепротерозойских постколлизионных гранитоидов юга Сибирского кратона // Петрология, 2005, т.13 (3), с. 253-279.

Донская Т.В., Гладкочуб Д.П., Мазукабзов А.М., Вингейт М.Т.Д. Раннепротерозойские постколлизионные гранитоиды Бирюсинского блока Сибирского кратона // Геология и геофизика, 2014, т. 55 (7), с. 1028-1043.

Донская Т.В., Гладкочуб Д.П., Мазукабзов А.М., Львов П.А., Дементерова Е.И., Мотова 3.Л. Саяно-Бирюсинский вулканоплутонический пояс (южная часть Сибирского кратона): возраст и петрогенезис // Геология и геофизика, 2019, т. 60 (1), с. 18-40. 
Загорский В.Е., Макагон В.М., Шмакин Б.М., Макрыгина В.А., Кузнецова Л.Г. Редкометалльные пегматиты. Т. 2. Гранитные пегматиты. Новосибирск, Наука, 1997, 285 с.

Загорский В.Е., Владимиров А.Г., Макагон В.М., Кузнецова Л.Г., Смирнов С.З., Дьячков Б.А., Анникова И.Ю., Шокальский С.П., Уваров А.Н. Крупные поля пегматитов в обстановках рифтогенеза и постколлизионных сдвигово-раздвиговых деформаций континентальной литосферы // Геология и геофизика, 2014, т. 55 (2), с. 303-322.

Ларин А.М., Сальникова Е.Б., Котов А.Б., Коваленко В.И., Рыцк Е.Ю., Яковлева С.3., Бережная Н.Г., Ковач В.П., Булдыгеров В.В., Срывцев Н.А. Северо-Байкальский вулканоплутонический пояс: возраст, длительность формирования и тектоническое положение // ДАН, 2003, т. 392, № 4, с. 506—511.

Левицкий В.И., Мельников А.И., Резницкий Л.З., Бибикова Е.В., Кирнозова Т.И., Козаков И.К., Макаров В.А., Плоткина Ю.В. Посткинематические раннепротерозойские гранитоиды юго-западной части Сибирской платформы // Геология и геофизика, 2002, т. 43 (8), c. 717-731.

Легенда Восточно-Саянской серии листов Государственной геологической карты Российской федерации масштаба 1:200000. /Под ред. Перфильева В.В., Галимовой Т.Ф. Иркутск, ГП Иркутскгеология, 1988, 200 с.

Николаева И.В., Палесский С.В., Козьменко О.А., Аношин Г.Н. Определение редкоземельных и высокозарядных элементов в стандартных геологических образцах методом масс-спектрометрии с индуктивно-связанной плазмой (ИСП-МС) // Геохимия, 2008, № 10, с. 1085-1091.

Ножкин А.Д. Раннепротерозойские окраинно-континентальные комплексы Ангарского складчатого пояса и особенности их металлогении // Геология и геофизика, 1999, т. 40 (11), с. 1524-1544.

Ножкин А.Д., Туркина О.М., Баянова Т.Б. Раннепротерозойские коллизионные и внутриплитные гранитоиды юго-западной окраины Сибирского кратона: петрогеохимические особенности, U-Pb геохронологические и Sm-Nd изотопные данные // ДАН, 2009, т. 428, №3, с. 386-391.

Сальникова Е.Б., Ларин А.М., Яковлева С.З., Котов А.Б., Глебовицкий В.А., Ткачев А.В., Анисимова И.В., Плоткина Ю.В., Гороховский Б.М. О возрасте Вишняковского месторождения редкометальных пегматитов (Восточный Саян): результаты U-Pb геохронологических исследований манганотанталита // ДАН, 2011, т. 441, №1, с. 72-76.

Сезько А.И. Основные этапы формирования континентальной коры Присаянья // Эволюция земной коры в докембрии и палеозое. Саяно-Байкальская горная область. Новосибирск, Наука, 1988, с. 5-41. 
Сезько А.И. Геология докембрия юго-запада Сибирской платформы и ее обрамления // Геология и геохронология докембрия Сибирской платформы и ее обрамления. Л., Наука, 1990, с. 38-49.

Туркина О.M., Прияткина Н.С. Изотопный Lu-Hf состав циркона и геохимия палеопротерозойских гранитоидов Бирюсинского блока (юго-запад Сибирского кратона) // Геосферные исследования, 2017, № 1, с. 60-72.

Туркина О.М., Капитонов И.Н. Источники палеопротерозойских коллизионных гранитоидов (Шарыжалгайский выступ, ЮЗ Сибирского кратона): от литосферной мантии до верхней коры // Геология и геофизика, 2019, т. 60 (4), с. 489-513.

Туркина О.М., Ножкин А.Д., Баянова Т.Б. Источники и условия образования раннепротерозойских гранитоидов юго-западной окраины Сибирского кратона // Петрология, 2006, т. 14 (3), с. 284-306.

Туркина О.M, Бережная Н.Г., Сухоруков В.П. Изотопный Lu-Hf состав детритового циркона из парагнейсов Шарыжалгайского выступа: свидетельства роста коры в палеопротерозое // Геология и геофизика, 2016, т. 57 (7), с. 1292-1306.

Эволюция земной коры в докембрии и палеозое (Саяно-Байкальская горная область) / В.Г. Беличенко, А.П. Шмотов, А.И. Сезько, А.Е. Ескин, Е.П. Васильев, Л.3. Резницкий, Р.Г. Боос, О.Р. Матисон. Новосибирск, Наука, 1988, 61 с.

Frost B.R., Barnes C.G., Collins W.J., Arculus R.J., Ellis D.J., Frost C.D. A geochemical classification for granitic rocks // J. Petrol., 2001, v. 42, p. 2033-2048.

Ludwig K.R. User’s manual for Isoplot/Ex, Version 2.10, A geochronological toolkit for Microsoft Excel. Berkeley Geochronology Center Special Publication. 1999, v. 1, 46 p.

Ludwig K.R. SQUID 1.00, A User's Manual; Berkeley Geochronology Center Special Publication. №.2, 2455 Ridge Road, Berkeley, CA 94709, USA. 2000, 19 p.

Miller C.F., Mittlefehldt D.W. Depletion of light rare earth elements in felsic magmas // Geology, 1982, v. 10, p. 129-133.

Miller C.F., McDowell S.M., Mapes R.W. Hot or cold granite? Implications of zircon saturation temperature and preservation of inheritance // Geology, 2003, v. 31, p. 529-532.

Vielzeuf, D., Montel, J.M., 1994. Partial melting of metagreywackes. Part I. Fluid-absent experiments and phase relationships // Contrib. Mineral. Petrol., v. 117, p. 375-393.

Watkins, J.M., Clemens, J.D., Treloar, P.J. Archaean TTGs as sources of younger granitic magmas: melting of sodic metatonalites at 0.6-1.2 GPa // Contrib. Mineral. Petrol., 2007, v. 154, p. 91-110. 
Watson E.B., Harrison T.M. Zircon saturation revisited: temperature and composition effects in a variety of crustal magma types // Earth Planet. Sci. Lett., 1983, v. 6, p. 295-304.

Williams I.S. U-Th-Pb geochronology by ion-microprobe. / Eds. M.A McKibben, III, W.C. Shanks, W.I. Ridley // Rev. Econ. Geol., 1998, v. 7, p. 1-35. 
Подрисуночные подписи к статье А.Д. Ножкина и др. «Геохимия и изотопный состав.....»

Рис. 1. Схема геологического строения северо-западной части Бирюсинского блока Присаянского выступа Сибирской платформы. Составлена по материалам авторов (Туркина и др., 2006; Дмитриева, Ножкин, 2012) и на основе геологической съемки ГФУГП «Иркутскгеология» [Геологическая..., 1982; Государственная..., 2000]. 1 поздненеопротерозойские осадочные отложения, 2 - нижнепротерозойские метаосадочновулканогенные образования (елашская серия), 3 - нижнепротерозойские метакарбонатнотерригенные породы (неройская серия), 4 - позднеархейский гнейсовый комплекс (хайламинский), 5 - раннедокембрийский мигматит-чарнокит-гранитогнейсовый комплекс (хадаминский). Интрузивные комплексы: 6 - раннепалеозойский гранит-граносиенитовый, 7 - палеопротерозойский гранитоидный, 8 - палеопротерозойский метагабброидный. 9-11 - геологические границы: 9 - разломы, 10- несогласного залегания, 11 - прочие границы. Буквы в кружках: ЕГ - Елашский грабен, П - Павловский гранитный массив. Прямоугольником показан контур схемы, приведенной на рис. 2.

Рис. 2. Схема размещения палеопротерозойских гранитоидов в нижнем течении р. Тагул. 1 - поздненеопротерозойские отложения, 2 - нижнепротерозойские терригенновулканогенные породы елашской серии, 3 - позднеархейские породы Бирюсинского блока, 4 - палеопротерозойские граниты и лейкограниты Павловского массива, 5 - метагабброиды, 6 - главные разломы (а) и прочие геологические границы (б), 7 - места отбора проб, 8 - место отбора пробы на U-Pb датирование циркона.

Рис. 3. Диаграмма с конкордией для цирконов из гранита Павловского массива.

Рис. 4. Диаграммы $\mathrm{SiO}_{2}-\mathrm{FeO}^{*} /\left(\mathrm{FeO}^{*}+\mathrm{MgO}\right), \mathrm{SiO}_{2}-\mathrm{ASI}, \mathrm{Zr}+\mathrm{Nb}+\mathrm{Ce}+\mathrm{Y}-\mathrm{FeO} / \mathrm{MgO}$ и $\mathrm{Yb}_{\mathrm{n}}$ - $(\mathrm{La} / \mathrm{Yb})_{n}$ для гранитов и кислых вулканитов Елашского грабена. 1- граниты и лейкограниты Павловского массива, 2 - кислые вулканиты р. Тагул, 3 - лейкограниты Топорокского массива, 4 - 5 - кислые вулканиты (участок Тагул и Топорок) [Донская и др., 2019].

Рис. 5. Редкоземельные и мультиэлементные спектры гранитов Павловского массива. а-б биотитовые граниты, в-г - лейкограниты.

Рис. 6. Редкоземельные и мультиэлементные спектры вулканитов Елашского грабена (р. Тагул). а-б - базальты и андезибазальты, в-г - кислые вулканиты. 
Таблица1.

$\mathrm{U}-\mathrm{Pb}$ изотопные данные для цирконов из гранита Павловского массива (обр. 257-81) Елашского грабена

\begin{tabular}{|c|c|c|c|c|c|c|c|c|c|c|c|c|c|c|c|c|c|}
\hline \multirow{2}{*}{$\begin{array}{c}\text { Зерно, } \\
\text { точка }\end{array}$} & \multirow{2}{*}{$\begin{array}{c}\% \\
{ }^{206} \mathrm{~Pb}_{\mathrm{c}}\end{array}$} & \multirow{2}{*}{$\begin{array}{c}\text { ppm } \\
\text { U }\end{array}$} & \multirow{2}{*}{$\begin{array}{l}\text { ppm } \\
\text { Th }\end{array}$} & \multirow{2}{*}{$\frac{{ }^{232} \mathrm{Th}}{{ }^{238} \mathrm{U}}$} & \multirow{2}{*}{$\underset{{ }^{206} \mathrm{~Pb}^{*}}{\mathrm{ppm}}$} & \multicolumn{2}{|c|}{$\begin{array}{l}\text { Возраст, } \\
\text { млн. лет }\end{array}$} & \multirow{2}{*}{$\begin{array}{l}\mathrm{D}, \\
\%\end{array}$} & \multirow{2}{*}{$\frac{{ }^{238} \mathrm{U}}{{ }^{206} \mathrm{~Pb}^{*}}$} & \multirow{2}{*}{ $\pm \%$} & \multirow{2}{*}{$\frac{{ }^{207} \mathrm{~Pb}^{*}}{{ }^{206} \mathrm{~Pb}^{*}}$} & \multirow{2}{*}{ $\pm \%$} & \multirow{2}{*}{$\frac{{ }^{207} \mathrm{~Pb}^{*}}{{ }^{235} \mathrm{U}}$} & \multirow{2}{*}{ $\pm \%$} & \multirow{2}{*}{$\frac{{ }^{206} \mathrm{~Pb}^{*}}{{ }^{238} \mathrm{U}}$} & \multirow{2}{*}{ $\pm \%$} & \multirow{2}{*}{ Rho } \\
\hline & & & & & & $\frac{{ }^{206} \mathrm{~Pb}}{{ }^{238} \mathrm{U}}$ & $\frac{{ }^{207} \mathrm{~Pb}}{{ }^{206} \mathrm{~Pb}}$ & & & & & & & & & & \\
\hline 1 & 2 & 3 & 4 & 5 & 6 & 7 & 8 & 9 & 10 & 11 & 12 & 13 & 14 & 15 & 16 & 17 & 18 \\
\hline 12,1 & 0,08 & 237 & 120 & 0,52 & 68,5 & $1871 \pm 17$ & $1845 \pm 14$ & -2 & 2,97 & 1,1 & 0,1128 & 0,77 & 5,24 & 1,3 & 0,337 & 1,1 & 0,81 \\
\hline 8,1 & 0,11 & 301 & 223 & 0,77 & 85 & $1834 \pm 26$ & $1830 \pm 14$ & -0 & 3,04 & 1,7 & 0,1119 & 0,75 & 5,08 & 1,8 & 0,329 & 1,7 & 0,91 \\
\hline 2,2 & 0,04 & 1832 & 135 & 0,08 & 521 & $1844 \pm 21$ & $1846 \pm 5$ & +0 & 3,02 & 1,3 & 0,1129 & 0,29 & 5,15 & 1,4 & 0,331 & 1,3 & 0,98 \\
\hline 10,1 & 0,06 & 109 & 68 & 0,65 & 30,7 & $1832 \pm 31$ & $1840 \pm 21$ & +0 & 3,04 & 2,0 & 0,1125 & 1,18 & 5,10 & 2,3 & 0,329 & 2,0 & 0,86 \\
\hline 4,1 & 0,01 & 881 & 204 & 0,24 & 247 & $1824 \pm 28$ & $1848 \pm 8$ & +1 & 3,06 & 1,8 & 0,1130 & 0,41 & 5,10 & 1,8 & 0,327 & 1,8 & 0,97 \\
\hline 6,1 & 0,01 & 1620 & 194 & 0,12 & 459 & $1838 \pm 20$ & $1865 \pm 5$ & +2 & 3,03 & 1,3 & 0,1141 & 0,30 & 5,19 & 1,3 & 0,330 & 1,3 & 0,97 \\
\hline 7,1 & 0,00 & 116 & 62 & 0,55 & 32,7 & $1827 \pm 19$ & $1858 \pm 22$ & +2 & 3,05 & 1,2 & 0,1136 & 1,22 & 5,13 & 1,7 & 0,328 & 1,2 & 0,70 \\
\hline 2,1 & 0,01 & 1863 & 190 & 0,11 & 520 & $1812 \pm 15$ & $1846 \pm 5$ & +2 & 3,08 & 0,9 & 0,1129 & 0,28 & 5,05 & 1,0 & 0,325 & 0,9 & 0,96 \\
\hline 9,1 & 0,03 & 1129 & 297 & 0,27 & 317 & $1823 \pm 17$ & $1858 \pm 7$ & +2 & 3,06 & 1,1 & 0,1136 & 0,37 & 5,12 & 1,1 & 0,327 & 1,1 & 0,94 \\
\hline 1,1 & 0,04 & 455 & 278 & 0,63 & 127 & $1812 \pm 24$ & $1848 \pm 11$ & +2 & 3,08 & 1,5 & 0,1130 & 0,58 & 5,06 & 1,6 & 0,325 & 1,5 & 0,93 \\
\hline 8,2 & 0,04 & 1853 & 325 & 0,18 & 517 & $1813 \pm 28$ & $1856 \pm 5$ & +3 & 3,08 & 1,7 & 0,1135 & 0,28 & 5,08 & 1,8 & 0,325 & 1,7 & 0,99 \\
\hline 5,1 & 0,08 & 449 & 30 & 0,07 & 123 & $1781 \pm 26$ & $1843 \pm 11$ & +4 & 3,14 & 1,7 & 0,1127 & 0,61 & 4,94 & 1,8 & 0,318 & 1,7 & 0,94 \\
\hline 13,1 & 0,15 & 238 & 284 & 1,23 & 64,4 & $1768 \pm 25$ & $1840 \pm 15$ & +4 & 3,17 & 1,6 & 0,1125 & 0,85 & 4,89 & 1,8 & 0,316 & 1,6 & 0,88 \\
\hline 3,1 & 0,00 & 3523 & 69 & 0,02 & 916 & $1704 \pm 22$ & $1829 \pm 4$ & +8 & 3,30 & 1,5 & 0,1118 & 0,21 & 4,67 & 1,5 & 0,303 & 1,5 & 0,99 \\
\hline 11,1 & 0,08 & 2975 & 104 & 0,04 & 754 & $1667 \pm 27$ & $1815 \pm 4$ & +9 & 3,39 & 1,9 & 0,1110 & 0,24 & 4,51 & 1,9 & 0,295 & 1,9 & 0,99 \\
\hline
\end{tabular}

Примечание.

Ошибки приведены на уровне $1 \sigma . \mathrm{Pb}_{c}$ и $\mathrm{Pb}^{*}$ - доли обыкновенного и радиогенного свинца, соответственно. Поправка на обыкновенный свинец проведена по измеренному ${ }^{204} \mathrm{~Pb}$. Ошибка калибровки стандарта TEMORA - 0,32\%. D - процент дискордантности. Rho - коэффициент корреляции ошибок отношений ${ }^{207} \mathrm{~Pb}^{*} / 235 \mathrm{U}$ и ${ }^{206} \mathrm{~Pb}^{*} / 238 \mathrm{U}$. 
Таблица 2.

Содержание петрогенных (мас. \%) и редких (г/т) элементов в гранитах Павловского массива и вулканитах елашской серии

\begin{tabular}{|c|c|c|c|c|c|c|c|c|c|}
\hline \multirow[t]{2}{*}{ проба } & 1 & 2 & 3 & 4 & 5 & 6 & 7 & 8 & 9 \\
\hline & $240-81$ & $257-81$ & $258-81$ & $259-81$ & $239-81$ & $245-81$ & $252-81$ & $308-91$ & $282-81$ \\
\hline $\mathrm{SiO}_{2}$ & 70 & 72.40 & 73.24 & 76.79 & 72.26 & 75.11 & 73.27 & 47.91 & 51.4 \\
\hline $\mathrm{TiO}_{2}$ & 0.74 & 0.30 & 0.19 & 0.164 & 0.3 & 0.08 & 0.62 & 1.69 & 1.94 \\
\hline $\mathrm{Al}_{2} \mathrm{O}_{3}$ & 14.2 & 14.20 & 14.34 & 12.78 & 13.66 & 13.27 & 13.05 & 13.55 & 13.66 \\
\hline $\mathrm{Fe}_{2} \mathrm{O}_{3}$ & 0.75 & 0.60 & 0.65 & 1.9 & 2.66 & 0.50 & 0.78 & 15.27 & 14.63 \\
\hline $\mathrm{FeO}$ & 2.06 & 1.44 & 2.15 & - & - & 0.66 & 1.24 & - & - \\
\hline $\mathrm{MnO}$ & 0.16 & 0.07 & 0.03 & 0.03 & 0.04 & 0.02 & 0.03 & 0.18 & 0.21 \\
\hline $\mathrm{MgO}$ & 1.3 & 0.30 & 0.38 & 0.38 & 0.6 & 0.12 & 0.9 & 5.81 & 5.4 \\
\hline $\mathrm{CaO}$ & 2.0 & 0.65 & 0.64 & 1.39 & 1.94 & 1.41 & 0.14 & 8.61 & 9.0 \\
\hline $\mathrm{Na}_{2} \mathrm{O}$ & 2.6 & 2.90 & 2.41 & 2.42 & 3.88 & 3.3 & 4.19 & 3.36 & 2.5 \\
\hline $\mathrm{K}_{2} \mathrm{O}$ & 4.92 & 5.64 & 5.47 & 3.13 & 2.99 & 4.36 & 4.6 & 0.28 & 0.36 \\
\hline $\mathrm{P}_{2} \mathrm{O}_{5}$ & 0.05 & 0.13 & 0.14 & 0.03 & 0.08 & 0.02 & 0.06 & 0.24 & 0.18 \\
\hline nnn & 1.24 & 0.95 & 0.45 & 1.1 & 1.74 & 0.65 & 0.98 & 3.67 & 1.58 \\
\hline сумма & 100.02 & 99.61 & 100.06 & 100.02 & 99.97 & 99.5 & 99.86 & 99.58 & 99.82 \\
\hline Th & 39 & 23.0 & 30 & 25 & 8.5 & 22 & 9 & 1.0 & 1.7 \\
\hline $\mathrm{U}$ & 3.5 & 5.6 & 3.3 & 2.3 & 1.9 & 3.8 & 2.8 & 0.2 & 0.6 \\
\hline $\mathrm{Rb}$ & 144 & 310 & 300 & 343 & 105 & 168 & 120 & 13 & 9.5 \\
\hline $\mathrm{Ba}$ & 727 & 435 & 307 & 347 & 317 & 384 & 380 & 91 & 100 \\
\hline $\mathrm{Sr}$ & 271 & 65 & 77 & 84 & 134 & 101 & 55 & 250 & 165 \\
\hline $\mathrm{La}$ & 36 & 29.0 & 30 & 57 & 10 & 12 & 12 & 5.9 & 7.2 \\
\hline $\mathrm{Ce}$ & 74 & 62.0 & 70 & 140 & 26 & 28 & 26 & 14.5 & 18 \\
\hline $\mathrm{Pr}$ & 7 & - & 7.8 & 16.8 & 2.8 & 3 & - & - & - \\
\hline $\mathrm{Nd}$ & 24 & 24.0 & 29 & 72 & 9.4 & 11.5 & 13 & 10 & 14 \\
\hline $\mathrm{Sm}$ & 4 & 5.3 & 5.9 & 15.7 & 2.1 & 2.6 & 3.2 & 3.4 & 4.4 \\
\hline $\mathrm{Eu}$ & 0.85 & 0.48 & 0.44 & 1.68 & 0.43 & 0.4 & $\begin{array}{l}0.8 \\
\end{array}$ & 1.35 & 1.62 \\
\hline Gd & 3.1 & 4.7 & 3.8 & 15.3 & 2.3 & 2.9 & 3.9 & 4.4 & 5.6 \\
\hline $\mathrm{Tb}$ & 0.48 & 0.67 & 0.55 & 2.6 & 0.39 & 0.48 & 0.7 & 0.8 & 1.1 \\
\hline Dy & 2.6 & - & 2.9 & 15.9 & 2.5 & 2.7 & - & - & - \\
\hline $\mathrm{Er}$ & 0.51 & - & 0.45 & 3.2 & 0.5 & 0.56 & - & - & - \\
\hline Ho & 1.44 & - & 1.18 & 9 & 1.4 & 1.68 & - & - & - \\
\hline $\mathrm{Tm}$ & 0.24 & 0.24 & 0.18 & 1.45 & 0.28 & 0.28 & 0.4 & - & - \\
\hline $\mathrm{Yb}$ & 1.56 & 1.38 & 1.1 & 8.9 & 1.9 & 1.8 & 2.6 & 3.5 & 4.2 \\
\hline $\mathrm{Lu}$ & 0.23 & 0.19 & 0.17 & 1.26 & 0.28 & 0.27 & 0.37 & 0.51 & 0.66 \\
\hline $\mathrm{Zr}$ & 165 & & 117 & 154 & 113 & 60 & 80 & - & - \\
\hline $\mathrm{Hf}$ & 4.8 & 3.4 & 3.6 & 5.5 & 4.1 & 2.5 & 3 & 2.4 & 3.4 \\
\hline $\mathrm{Ta}$ & 1.2 & 2.2 & 2.4 & 2.1 & 1.2 & 1.81 & 2.4 & 0.25 & - \\
\hline $\mathrm{Nb}$ & 12 & - & 17 & 27 & 9.3 & 8 & 14 & - & - \\
\hline $\mathrm{Y}$ & 15 & - & 13.5 & 86 & 14 & 18 & 26 & - & - \\
\hline$(\mathrm{La} / \mathrm{Yb})_{\mathrm{n}}$ & 15.6 & 14.2 & 18.4 & 4.3 & 3.5 & 4.5 & 3.1 & 1.1 & 1.2 \\
\hline $\mathrm{Eu} / \mathrm{Eu}^{*}$ & 0.7 & 0.3 & 0.3 & 0.3 & 0.6 & 0.4 & 0.7 & 1.1 & 1.0 \\
\hline
\end{tabular}

Примечание. Павловский массив: 1-4 - порфировидные граниты, 5-7 - лейкограниты; елашская серия: 8-10 - базальты, 11 - андезибазальт и 12-18 - кислые вулканиты. Прочерк - нет данных. $\mathrm{Fe}_{2} \mathrm{O}_{3 \text { tot }}$ - суммарное содержание железа. 
Окончание табл. 2.

\begin{tabular}{|c|c|c|c|c|c|c|c|c|c|}
\hline \multirow[t]{2}{*}{ проба } & 10 & 11 & 12 & 13 & 14 & 15 & 16 & 17 & 18 \\
\hline & 299-81 & $291-81$ & $288-81$ & 289-81 & $287-81$ & $295-81$ & 296-81 & $297-81$ & $10-16$ \\
\hline $\mathrm{SiO}_{2}$ & 48.78 & 55.74 & 74.72 & 71.44 & 74.78 & 75.05 & 79.34 & 75.77 & 75.76 \\
\hline $\mathrm{TiO}_{2}$ & 1.05 & 0.87 & 0.25 & 0.28 & 0.23 & 0.56 & 0.26 & 0.32 & 0.52 \\
\hline $\mathrm{Al}_{2} \mathrm{O}_{3}$ & 15.32 & 13.95 & 12.7 & 13.75 & 12.34 & 12.05 & 9.80 & 11.17 & 11.19 \\
\hline $\mathrm{Fe}_{2} \mathrm{O}_{3 \text { tot }}$ & 11.3 & 10.35 & 2.90 & 4.08 & 3.21 & 4.12 & 2.97 & 3.80 & 4.58 \\
\hline $\mathrm{MnO}$ & 0.21 & 0.28 & 2.90 & 4.08 & 3.21 & 4.12 & 2.97 & 3.80 & 4.58 \\
\hline $\mathrm{MgO}$ & 6.7 & 6.71 & 0.08 & 0.07 & 0.10 & 0.14 & 0.08 & 0.03 & 0.09 \\
\hline $\mathrm{CaO}$ & 12.37 & 5.7 & 0.4 & 1.12 & 0.95 & 1.0 & 0.62 & 1.25 & 1.12 \\
\hline $\mathrm{Na}_{2} \mathrm{O}$ & 2.53 & 1.35 & 1.66 & 1.63 & 1.79 & 1.66 & 1.92 & 1.94 & 0.78 \\
\hline $\mathrm{K}_{2} \mathrm{O}$ & 0.45 & 2.99 & 2.37 & 1.11 & 1.78 & 0.32 & 1.06 & 1.70 & 1.64 \\
\hline $\mathrm{P}_{2} \mathrm{O}_{5}$ & 0.15 & 0.23 & 3.7 & 4.40 & 3.38 & 3.13 & 2.97 & 3.25 & 2.64 \\
\hline nnn & 1.9 & 2.27 & 0.08 & 0.07 & 0.05 & 0.12 & 0.05 & 0.06 & 0.11 \\
\hline сумма & 99.85 & 99.74 & 0.8 & 1.96 & 1.22 & 1.73 & 0.49 & 0.65 & 0.90 \\
\hline Th & 0.9 & 5.3 & 15.8 & 17.1 & 16.1 & 14.3 & 14.7 & 12.6 & 12.8 \\
\hline $\mathrm{U}$ & 0.3 & 1.1 & 3.7 & 3.2 & 3.1 & 4.8 & 2.5 & 2.8 & 2.4 \\
\hline $\mathrm{Rb}$ & 12 & 155 & 139 & 175 & 129 & 178 & 125 & 138 & 130 \\
\hline $\mathrm{Ba}$ & 109 & 307 & 740 & 641 & 624 & 329 & 177 & 531 & 502 \\
\hline $\mathrm{Sr}$ & 235 & 110 & 84 & 61 & 79 & 47 & 42 & 131 & 99 \\
\hline $\mathrm{La}$ & 2.8 & 18.1 & 32 & 46 & 40 & 53 & 39 & 32 & 35 \\
\hline $\mathrm{Ce}$ & 7.2 & 36 & 67 & 92 & 85 & 88 & 99 & 70 & 70 \\
\hline $\mathrm{Pr}$ & - & - & 7.9 & 11.2 & 10.2 & 10.5 & 9.9 & 7.4 & 7.8 \\
\hline $\mathrm{Nd}$ & 5.2 & 18.5 & 32 & 44 & 38 & 40 & 35 & 28 & 30 \\
\hline $\mathrm{Sm}$ & 1.86 & 4.3 & 6.7 & 8.2 & 7.9 & 7.0 & 6.1 & 4.9 & 5.6 \\
\hline $\mathrm{Eu}$ & 0.7 & 1.4 & 1.02 & 1.33 & 1.24 & 1.21 & 0.92 & 0.97 & 0.88 \\
\hline $\mathrm{Gd}$ & 2.3 & 3.9 & 6.8 & 8.0 & 6.6 & 6.6 & 4.8 & 4.1 & 4.4 \\
\hline $\mathrm{Tb}$ & 0.44 & 0.75 & 1.19 & 1.24 & 1.07 & 1.07 & 0.66 & 0.67 & 0.67 \\
\hline Dy & - & - & 7.7 & 8.0 & 6.3 & 6.7 & 4.0 & 4.1 & 3.8 \\
\hline Ho & - & - & 1.72 & 1.73 & 1.39 & 1.49 & 0.84 & 0.87 & 0.84 \\
\hline $\mathrm{Er}$ & - & - & 4.8 & 4.8 & 3.9 & 4.2 & 2.5 & 2.4 & 2.3 \\
\hline $\mathrm{Tm}$ & - & - & 0.76 & 0.72 & 0.62 & 0.61 & 0.40 & 0.36 & 0.37 \\
\hline $\mathrm{Yb}$ & 1.8 & 2.5 & 4.9 & 4.7 & 4.0 & 3.8 & 2.5 & 2.4 & 2.4 \\
\hline $\mathrm{Lu}$ & 0.27 & 0.35 & 0.73 & 0.72 & 0.59 & 0.57 & 0.36 & 0.36 & 0.36 \\
\hline $\mathrm{Zr}$ & - & - & 147 & 171 & 146 & 278 & 148 & 142 & 292 \\
\hline $\mathrm{Hf}$ & 1.3 & 2.5 & 4.5 & 5.1 & 4.4 & 6.4 & 3.9 & 3.7 & 6.9 \\
\hline $\mathrm{Ta}$ & 0.25 & 0.44 & 1.21 & 1.32 & 1.09 & 1.12 & 0.93 & 0.93 & 1.25 \\
\hline $\mathrm{Nb}$ & - & - & 16.9 & 19.0 & 16.6 & 15.8 & 10.7 & 9.9 & 12.8 \\
\hline $\mathrm{Y}$ & - & - & 48 & 49 & 38 & 50 & 23 & 25 & 24 \\
\hline$(\mathrm{La} / \mathrm{Yb})_{\mathrm{n}}$ & 1.0 & 4.9 & 4.3 & 6.6 & 6.6 & 9.3 & 10.5 & 8.9 & 9.7 \\
\hline $\mathrm{Eu} / \mathrm{Eu}^{*}$ & 1.0 & 1.0 & 0.3 & 0.3 & 0.4 & 0.4 & 0.4 & 0.5 & 0.4 \\
\hline
\end{tabular}


Таблица 3.

Распределение радиоактивных элементов в гранитоидах и пегматитах Павловского массива и кислых вулканитах

\begin{tabular}{|l|c|c|c|c|c|}
\hline \multicolumn{1}{|c|}{ Порода } & $\mathrm{n}$ & $\mathrm{U}$, г/T & $\mathrm{Th}, \Gamma / \mathrm{T}$ & $\mathrm{K}, \%$ & $\mathrm{Th} / \mathrm{U}$ \\
\hline Граниты порфировидные биотитовые & 11 & $3.8 \pm 0.7$ & $23.4 \pm 1.3$ & $3.85 \pm 0.5$ & 6.2 \\
\hline Граниты лейкократовые & 8 & $3.3 \pm 0.5$ & $12.4 \pm 1.8$ & $4.27 \pm 0.3$ & 3.8 \\
\hline $\begin{array}{l}\text { Пегматиты зональные с аплитовой } \\
\text { оторочкой, альбитизированные, } \\
\text { редкометалльные }\end{array}$ & 9 & $5.0 \pm 1.6$ & $7.2 \pm 4.9$ & $2.0 \pm 0.1$ & 1.5 \\
\hline Кислые вулканиты & 7 & $3.2 \pm 0.8$ & $14.8 \pm 1.7$ & $2.92 \pm 0.6$ & 4.8 \\
\hline
\end{tabular}

Примечание. $\mathrm{n}$ - число проб. 
Таблица 4.

Sm-Nd изотопные данные для пород Бирюсинского блока и Елашского грабена

\begin{tabular}{|l|l|l|l|l|l|l|l|l|}
\hline № & $\begin{array}{l}\text { порода, } \\
\text { номер } \\
\text { образца }\end{array}$ & $\begin{array}{l}\text { T, } \\
\text { млн } \\
\text { лет }\end{array}$ & $\begin{array}{l}\mathrm{Sm}, \\
\text { Г/ }\end{array}$ & $\begin{array}{l}\mathrm{Nd}, \\
\text { Г/ }\end{array}$ & ${ }^{147} \mathrm{Sm} /{ }^{144} \mathrm{Nd}$ & ${ }^{143} \mathrm{Nd} /{ }^{144} \mathrm{Nd}$ & $\mathrm{T}_{\mathrm{Nd}}(\mathrm{DM})$ & $\varepsilon_{\mathrm{Nd}}(\mathrm{t})$ \\
\hline 1 & $9-00$ & 2500 & 6.47 & 31.18 & 0.105162 & $0.511311 \pm 8$ & 2572 & 3.6 \\
\hline 2 & $33-81$ & 2500 & 5.44 & 30.13 & 0.109133 & $0.511212 \pm 13$ & 2811 & 0.3 \\
\hline 3 & $38-81$ & 2500 & 5.87 & 32.68 & 0.108626 & $0.511336 \pm 11$ & 2620 & 2.9 \\
\hline 4 & $253-81$ & 1850 & 2.71 & 18.27 & 0.089580 & $0.511232 \pm 21$ & 2347 & -2.0 \\
\hline 5 & $258-81$ & 1850 & 5.55 & 26.54 & 0.12638 & $0.0511613 \pm 8$ & 2672 & -3.3 \\
\hline 6 & $289-81$ & 1870 & 8.18 & 40.83 & 0.121056 & $0.511636 \pm 11$ & 2482 & -1.4 \\
\hline 7 & $308-81$ & 1870 & 3.85 & 12.95 & 0.179950 & $0.512618 \pm 8$ & - & 3.5 \\
\hline
\end{tabular}

Примечание. Хайламинская серия: 1 - парагнейс, 2-3 - ортогнейсы; 4-5 - Павловский массив: 4 - плагиогранит; 5 - порфировидный гранит; Елашский грабен: 6 - кислый метавулканит; 7 - метабазальт. 


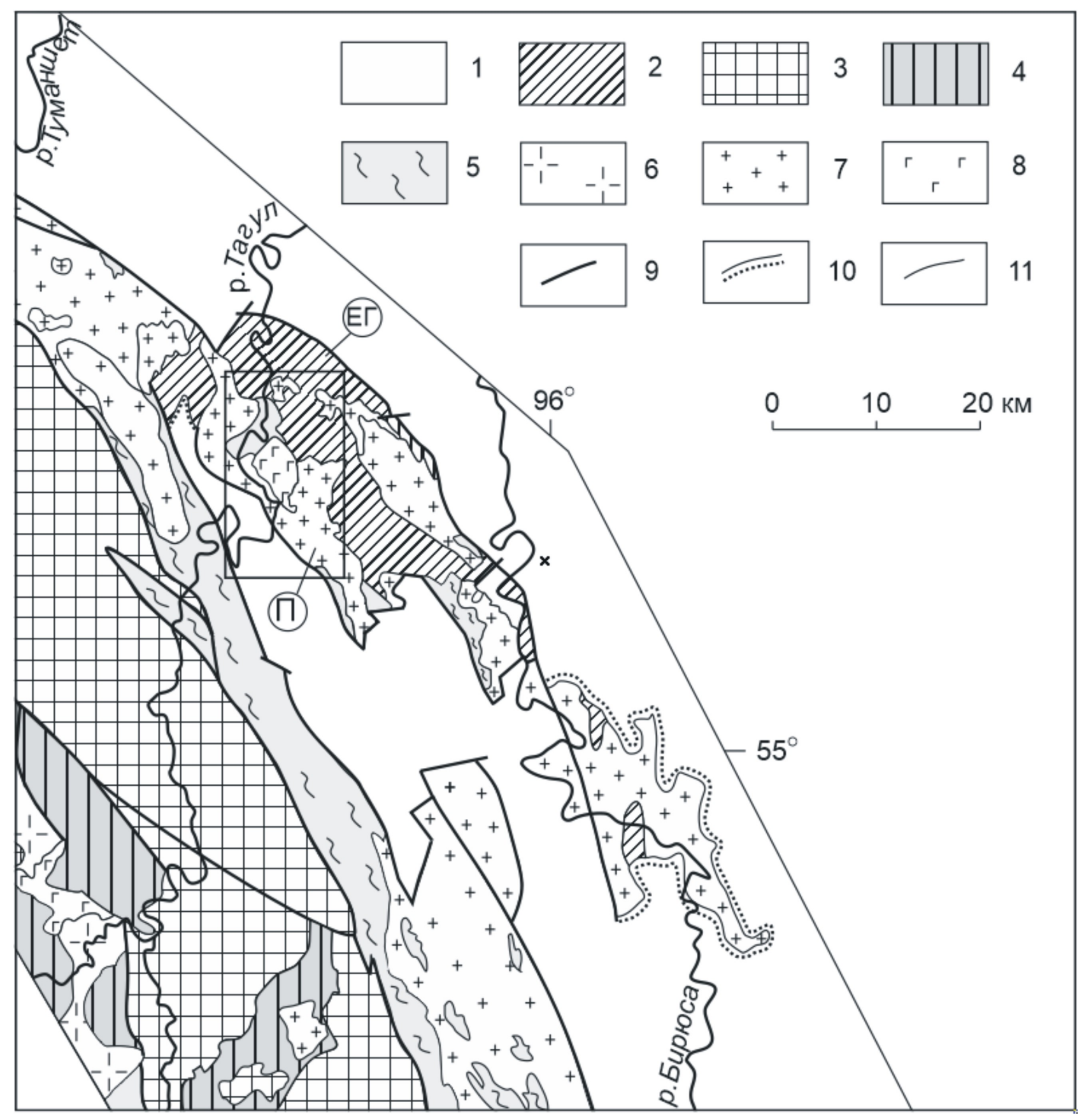




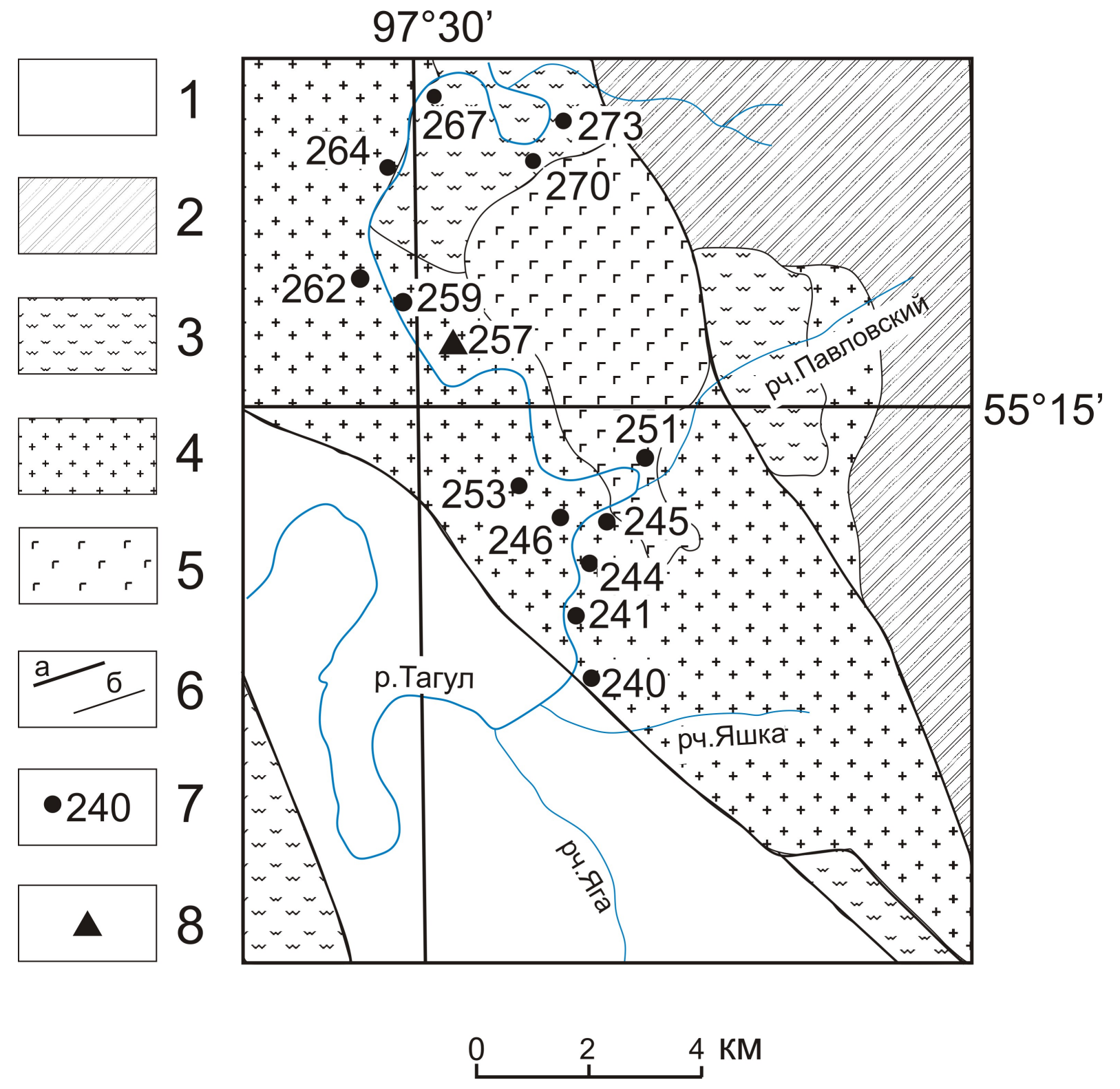




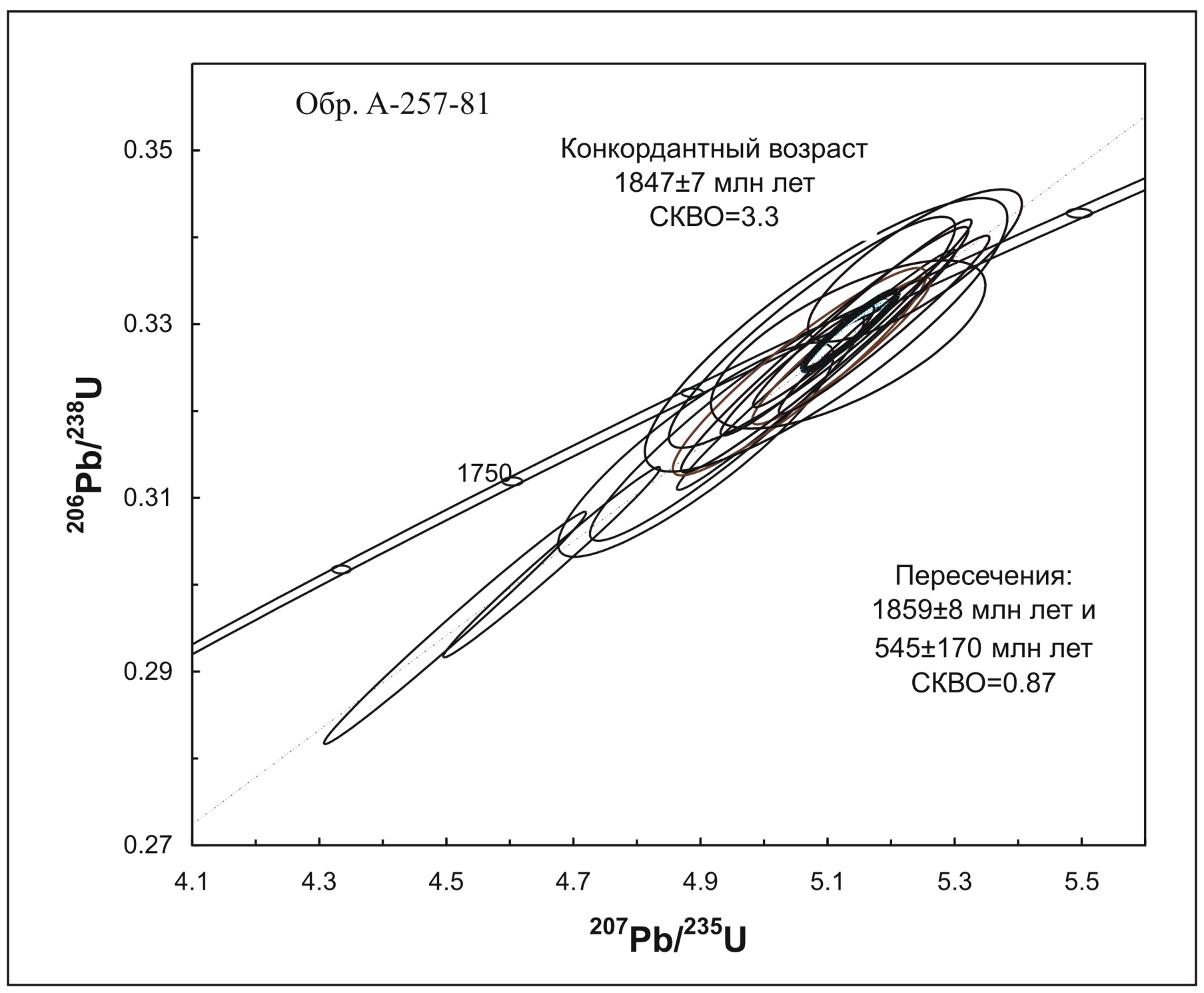



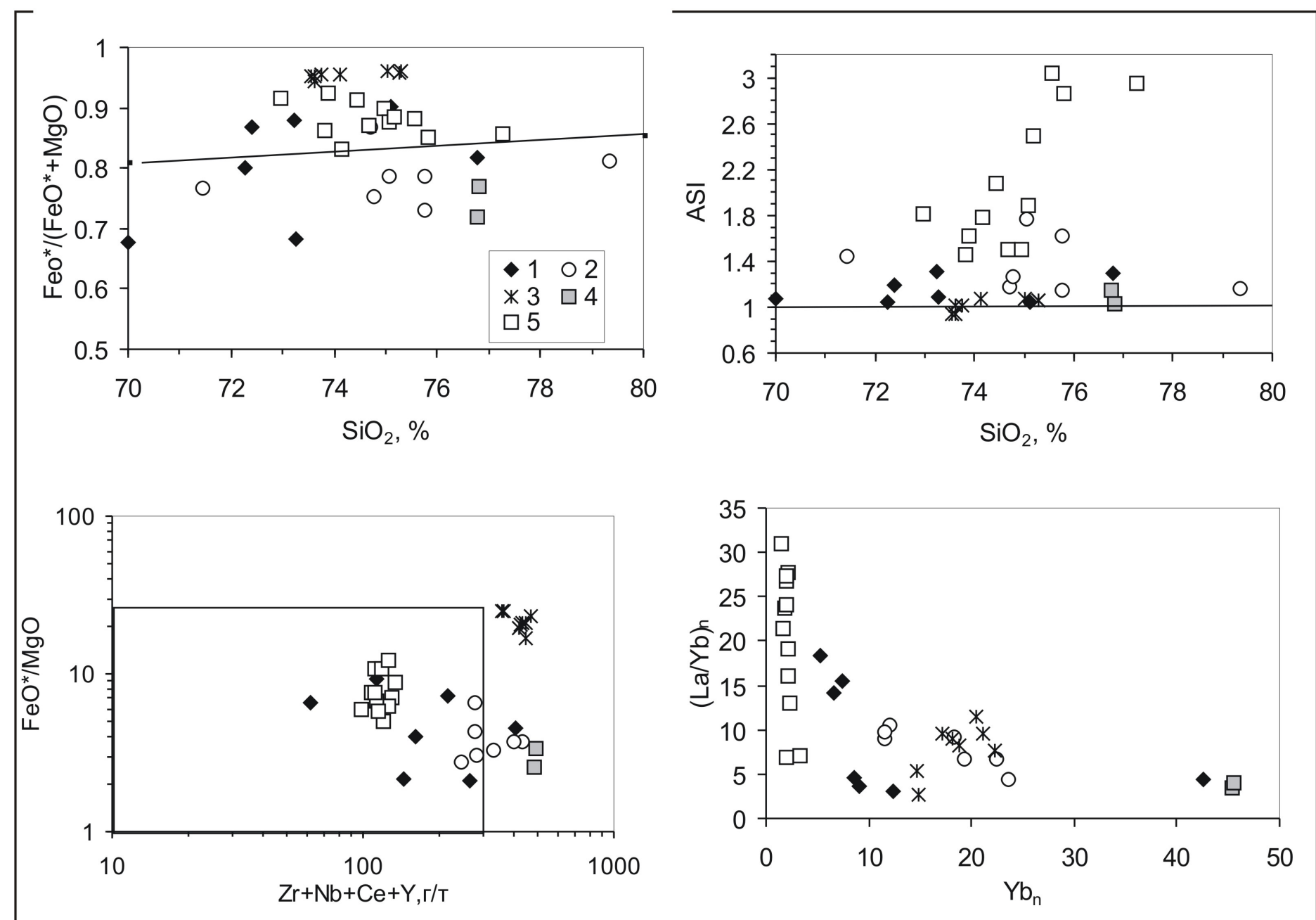


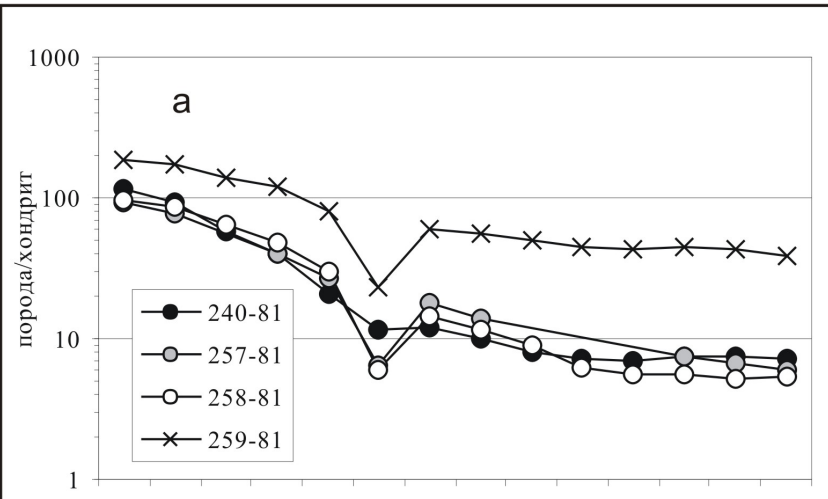

La Ce Pr Nd Sm Eu Gd Tb Dy Ho Er $\mathrm{Tm}$ Yb $\mathrm{Lu}$

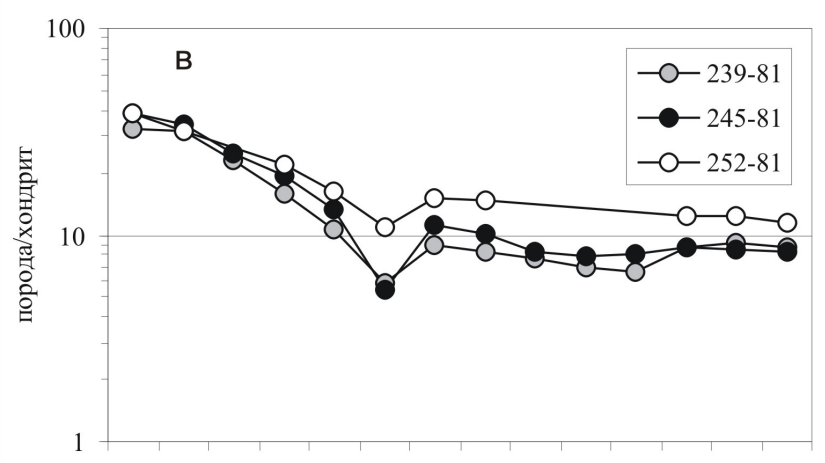

La Ce Pr Nd Sm Eu Gd Tb Dy Ho Er Tm Yb Lu

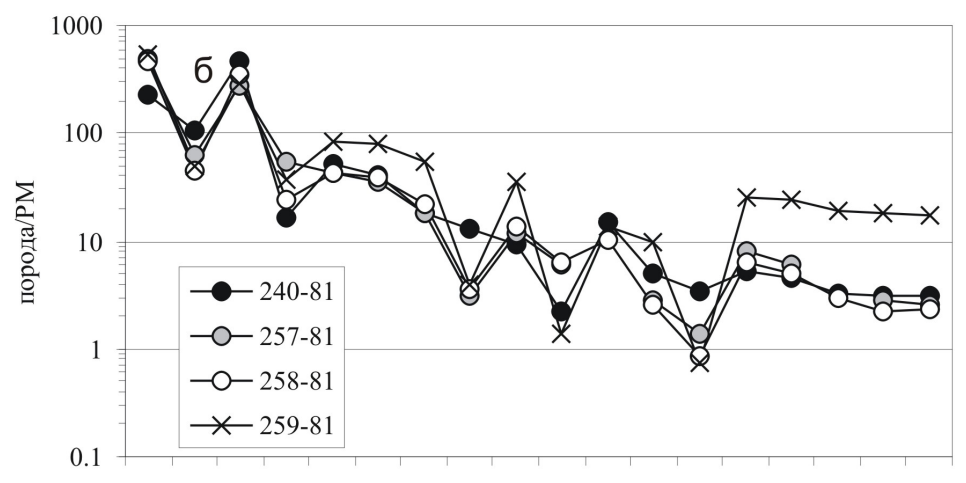

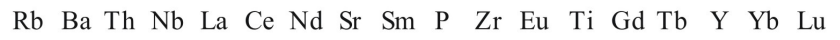

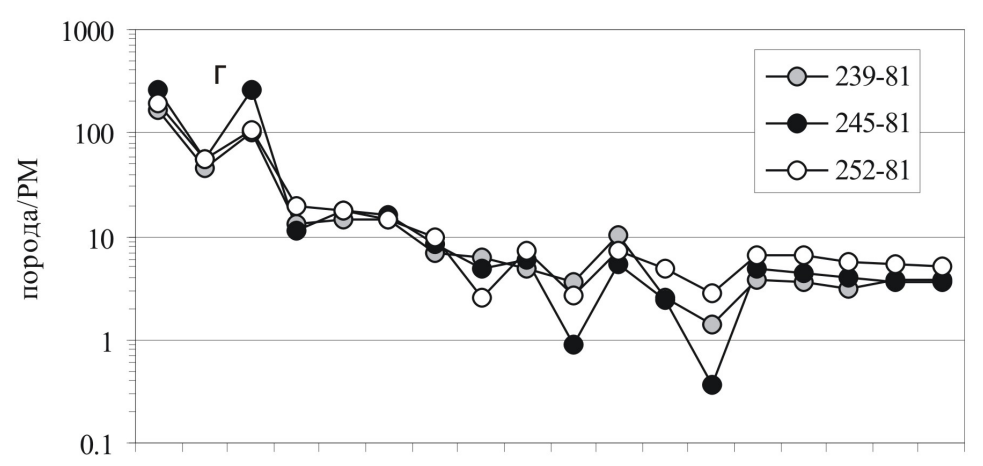

$\mathrm{Rb} \mathrm{Ba}$ Th Nb La Ce Nd Sr Sm P Zr Eu Ti Gd Tb Y Yb Lu 

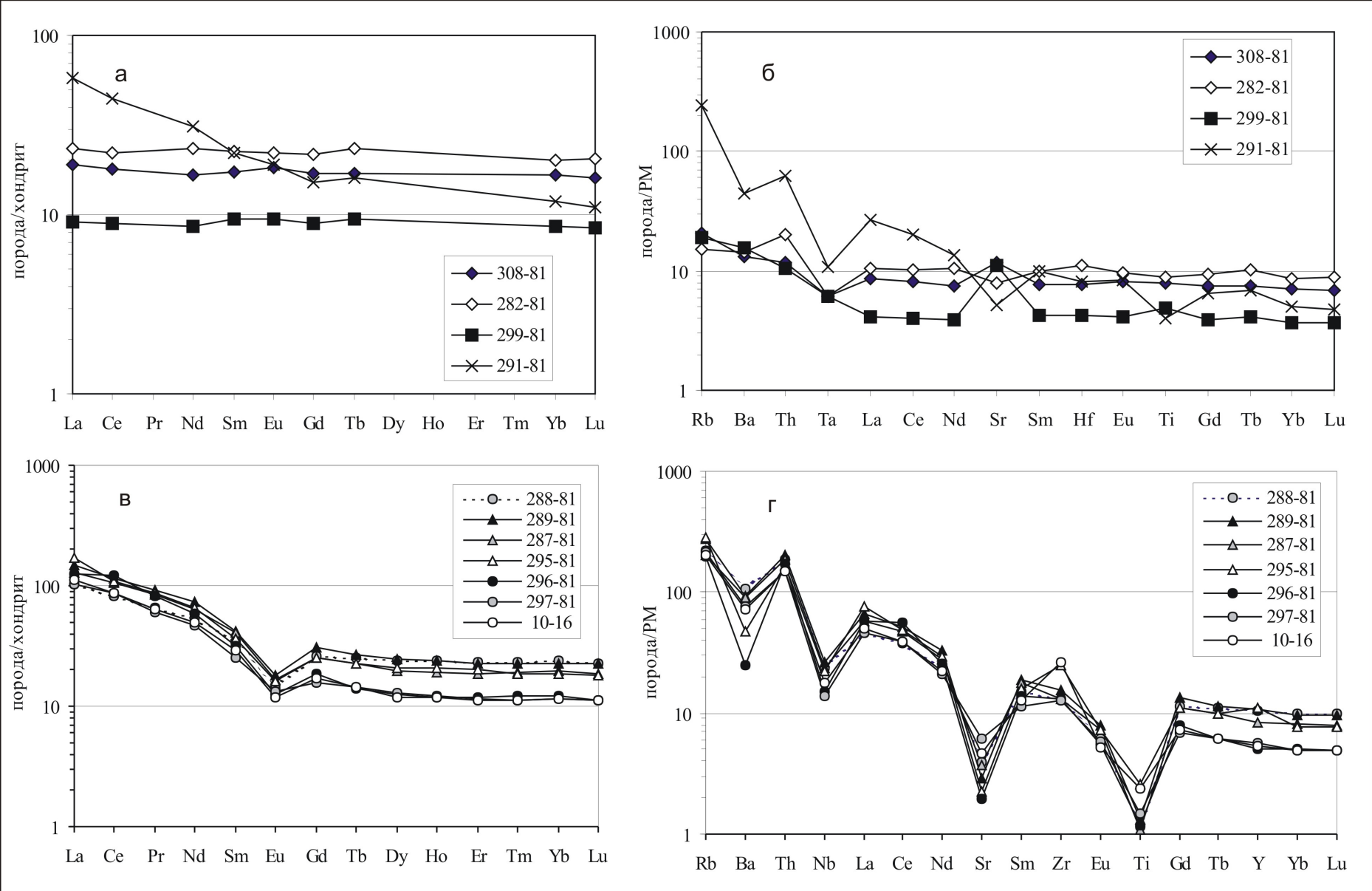